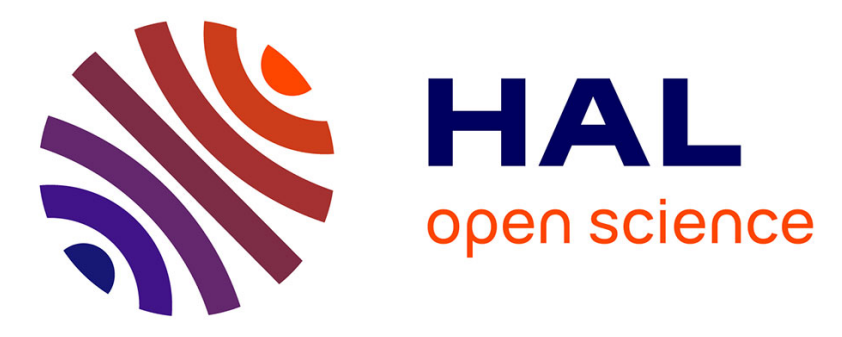

\title{
Meiobenthos and free-living nematodes as tools for biomonitoring environments affected by riverine impact
}

F Semprucci, F Frontalini, C Sbrocca, E Armynot Du Châtelet, Viviane Bout-roumazeilles, R Coccioni, M Balsamo

\section{- To cite this version:}

F Semprucci, F Frontalini, C Sbrocca, E Armynot Du Châtelet, Viviane Bout-roumazeilles, et al.. Meiobenthos and free-living nematodes as tools for biomonitoring environments affected by riverine impact. Environmental Monitoring and Assessment, 2015, 187 (5), pp.251. 10.1007/s10661-015-44937. hal-03280555

\section{HAL Id: hal-03280555 https://hal.science/hal-03280555}

Submitted on 15 Jul 2021

HAL is a multi-disciplinary open access archive for the deposit and dissemination of scientific research documents, whether they are published or not. The documents may come from teaching and research institutions in France or abroad, or from public or private research centers.
L'archive ouverte pluridisciplinaire HAL, est destinée au dépôt et à la diffusion de documents scientifiques de niveau recherche, publiés ou non, émanant des établissements d'enseignement et de recherche français ou étrangers, des laboratoires publics ou privés. 


\title{
Meiobenthos and free-living nematodes as tools for biomonitoring environments affected by riverine impact
}

\author{
F. Semprucci ${ }^{\mathrm{a},{ }^{*}}$, F. Frontalini ${ }^{\mathrm{a}}$, C. Sbrocca ${ }^{\mathrm{a}}$, E. Armynot du Châtelet ${ }^{\mathrm{b}}$, V. Bout-Roumazeilles ${ }^{\mathrm{b}}$, \\ R. Coccioni ${ }^{\mathrm{a}}$, M. Balsamo ${ }^{\mathrm{a}}$
}

${ }^{\text {a }}$ Dipartimento di Scienze della Terra, della Vita e dell'Ambiente (DiSTeVA), Università degli Studi di Urbino 'Carlo Bo', Campus Scientifico loc. Crocicchia, 61029 Urbino, Italy

${ }^{\mathrm{b}}$ UMR 8217 CNRS Géosystèmes, Université Lille 1, UFR Sciences de la Terre, Bât SN5, Avenue Paul Langevin, 59655 Villeneuve d'Ascq, France

* corresponding author

e-mail: federica.semprucci@uniurb.it

\begin{abstract}
The effects of the human impact on the coastal environments and relative biota can be different and even greater than those derived by natural fluctuations. The major disturbance causes in the coastal systems are rivers that may be important sources of nutrients and pollutants, particularly in a semi-closed basin such as the Adriatic Sea. In this context, we investigated the distribution of both meiobenthic and nematode assemblages in the Central Adriatic Sea to evaluate whether and how they are influenced by riverine discharges and which faunal descriptors are the most effective in detecting this type of stress. On the basis of our results, the disturbance effects in the studied area might be caused by both local streams and Po plume, and even if the latter might be considered of lesser extent, it is worthy to note its real impact at a short distance from the coastline. Meiobenthic assemblage structure appears as a good tool for detecting short-term responses of the benthic domain, whereas nematode assemblages seem more useful for defining long-term responses. Accordingly, the former highlighted from poor to sufficient ecological quality status (EQS) of this area, whereas the latter from moderate to bad EQS. Life strategy traits prove to be the most informative faunal descriptor due to their high correspondence with the environmental variables and, particularly with this type of disturbance.
\end{abstract}

\section{Keywords}

Meiofauna. Nematodes, Water Framework Directive, Bioindicators, Water quality, Po river plume 


\section{Introduction}

absolute standards for biological quality of waters can be applied across the European Union because of ecological and environmental heterogeneity. The Water Framework Directive (WFD), 2000/60/EC, and the Marine Strategy Framework Directive (MSFD), 2008/56/EC, aim at defining the baseline of a good ecological status for any water body. For the WFD, a variety of indices, target values and reference setting approaches for assessing the ecological quality status (EQS) have been developed, intercalibrated and discussed. Accordingly, EQS has been mainly evaluated through the analysis of macrofauna (Borja et al. 2000; Simboura and Zenetos 2002; Borja and Dauer 2008) and, only in few cases, of meiofauna (Moreno et al. 2011; Semprucci et al. 2014a, b).

Nevertheless, the use of meiobenthic organisms could present many advantages over macro invertebrates owing to their high abundance and diversity, small size, short life and reproductive cycles, rapid development, limited mobility, absence of pelagic life stages and the presence of both tolerant and sensitive species (Kennedy and Jacoby 1999).

Foraminifera, nematodes and copepods are taxa generally considered to be the most suitable for studying the ecological conditions of the meiobenthic community (see Balsamo et al. 2010, 2012 for review). In particular, nematodes have also the ability to survive in extremely polluted conditions and are usually the only persistent taxon in heavily polluted/stressed habitats (Coull and Chandler 1992). Nematodes play a key role in ecosystem functioning, thanks to their crucial position in the food chains (Gallucci et al. 2005; Moens et al. 2005; Balsamo et al. 2010 for review). All these peculiarities, along with the high stability of populations, make nematodes a potential tool for detecting environmental changes through their rapid and unequivocal responses compared with those of macrobenthos (Heip et al. 1985; Bongers and Van de Haar 1990). Moreover, nematodes are easy to collect, and provide a highly reliable database for statistical analysis, even when only a limited volume of samples is available (Platt and Warwick 1980).

On a worldwide scale, the increasing impact of human activities on marine and estuarine ecosystems triggered the creation of new monitoring strategies aimed to assess and maintain their ecological integrity (Karr 1999) to promote their long-term sustainability (Borja and Dauer 2008). With this background, a survey on the meiobenthic assemblages of an area of the Central Adriatic Sea characterised by a gradient of anthropogenic disturbance has been carried out (Semprucci et al. 2013a). Nematode assemblages have been studied from a taxonomic and functional point of view in order both to define the EQS in accordance with 
the European Directives' standards and to discuss possible meiofaunal or nematode descriptors for the ecological quality assessment of the coastal marine ecosystems. In particular, the following questions have been addressed: (a) Are there significant differences in the meiofaunal and in the nematode assemblages imputable to the anthropogenic disturbance? (b) Do meiobenthic and nematode assemblages show the same type of response to possible environmental changes? (c) Which of all the tested faunal descriptors are the best indicators of riverine disturbance?

\section{Material and methods}

Study area and sampling sites

The Adriatic Sea (Central Mediterranean) is a basin characterised by an extremely long and morphologically complex coastline (Artegiani et al. 1997). The general circulation of the Adriatic Sea is cyclonic and mainly determines the distribution of the runoff products introduced by the rivers (Artegiani et al. 1997). Moreover, regionally, local currents (i.e. longshore and rip currents) may assume great importance in the transport of the sediments (see Semprucci et al. 2010 for further details). The investigated area is located in the northern part of the Marche region (Italy) and extends from Gabicce to Fano cities (Pesaro-Urbino) (Fig. 1). Here, the main pollution sources are tourist-related activities that produce most of the urban sewage from coastal cities. Meanwhile, the area is mainly characterised by the outflow of three rivers, Foglia, Metauro and Tavollo (Fig. 1). The combined flow of these rivers, that have a torrential regime, is ten times less than Po river flow (Penna et al. 2004). In detail, the Foglia River (FO site), which flows through the city of Pesaro, is the major source of pollution, carrying wastewater from urban and industrial areas and livestock farms (Gaudiano et al. 1994). Its water has been reported to be of low quality, particularly at the mouth (FO site), where an unstructured macrobenthic community and only a few highly tolerant taxa have been found (Frontalini et al. 2011). The Metauro River (M site) flows south $(\sim 3 \mathrm{~km})$ of Fano, and its hydrographical basin $(1264 \mathrm{~km} 2)$ is one of the widest of Marche. In the last years, the water quality of Metauro has been described as adequate and suitable for fish life (Frontalini et al. 2011). Monte Brisighella (B site) and Fiorenzuola di Focara (FI site) sampling sites are enclosed in the Natural Regional Park of Monte San Bartolo (Fig. 1). The park was created in 1997 to protect this terrestrial area of great naturalistic importance, and it proved to host also a high diversity of marine benthic assemblages (Mosci et al. 2002). From previous studies, at FI and B sites, inside the natural park, the level of human disturbance appeared overall lower than in the neighbouring area of the FO site, showing a better EQS 
(Semprucci et al. 2013a). Accordingly, two sites were selected in front of the local mouth rivers ( $\mathrm{M}$ and $\mathrm{FO}$ ) and two sites characterised by a documented low level of human disturbance (FI and B).

\section{Sampling operations}

Samples were collected from each site in two different periods, November 2011 (N11) and June 2012 (J12) according to Semprucci et al. (2010, 2013). During the sampling collection, sediment samples were collected at $500 \mathrm{~m}$ from the coastline at ca. $5 \mathrm{~m}$ depth by means of a modified Van Veen grab (volume 201 , area $400^{\circ}-220 \mathrm{~mm}$ ). This modified grab model permits the insertion of a Plexiglas corer into the central part of the grab, enabling portions of almost completely undisturbed sediments to be collected (Moreno et al. 2011). For the study of meiobenthos, three replicate cores (surface area $6 \mathrm{~cm} 2$ each) were taken down to a depth of $9 \mathrm{~cm}$; the sediment was then treated with $7 \% \mathrm{MgCl} 2$ for specimen narcotization, fixed with $4 \%$ neutralised formalin in sea water and then stained with Rose Bengal (2 $\mathrm{g}$ of Rose Bengal in $1000 \mathrm{ml}$ of ethyl alcohol) (Danovaro et al. 2004). Two aliquots of sediments were also taken for grain-size analysis and determination of the organic matter and stored at $-20{ }^{\circ} \mathrm{C}$. During the sampling, temperature, salinity, dissolved oxygen (DO) concentration, $\mathrm{pH}$, redox profile (ORP) and chlorophyll-a (Chl-a) content were also measured in the water column using a multiparametric probe (IDRONAUT), but only the bottom water parameters are considered in the statistical analysis.

\section{Sediment parameter analyses}

Sediment grain-size analyses were performed using the principle of diffraction and diffusion of a monochromatic laser beam on suspended particles (Malvern Mastersizer 2000, red He-Ne laser, 632 and $466 \mathrm{~nm}$ wavelengths). The method is based on near-forward scattering of a laser beam by particles in suspension (Loizeau et al. 1994). Measurements can range from 0.02 to $2000 \mu \mathrm{m}$ with an obscuration comprised between 10 and $20 \%$. The method and the principle of diffraction for sediment grain-size analyses are deeply described in Trentesaux et al. (2001). Three main fractions, clay $(<2 \mu \mathrm{m})$, silt $(2$ to $63 \mu \mathrm{m})$ and sand (63 to $2000 \mu \mathrm{m})$, were considered.

Clay minerals are derived either from the weathering of the rocks of the surroundings and are brought to sea by winds/rivers or come from more distant sources and are transported by marine currents. They may also originate from the in situ alteration of some minerals. Clay 
mineralogy was therefore used to evaluate the major sources of the sediment deposited within the present sampling area. Clay minerals are characterised by their layer plus interlayer interval as revealed by X-ray diffraction (XRD) analysis. Smectite is characterised by a peak at $14 \AA$ on the untreated sample test, which expands to $17 \AA$ after saturation in ethylene glycol and retracts at $10 \AA$ after heating. Illite presents a basal peak at $10 \AA$ on the three tests (natural, glycolated and heated). Chlorite is characterised by permanent peaks at 14, 7, 4.75 and $3.54 \AA$. Kaolinite is characterised by peaks at 7 and $3.58 \AA$ on the untreated sample and after saturation in ethylene glycol. Both peaks disappear or are strongly reduced after heating. Semi-quantitative estimation of clay mineral abundances, based on the pseudo-voigt deconvolution for the doublet kaolinite- chlorite (3.58-3.54 $\AA$ ), was performed using the software MacDiff developed by Petschick (2001). Here we use the illite to smectite ratio to evaluate the balance between inputs from rivers, namely Po River (illite) and eastern Apennine rivers (smectite). These ratios are calculated using the semi-quantitative estimation of each clay mineral (Bout-Roumazeilles et al. 2013; Combourieu-Nebout et al. 2013). The error on the reproducibility of measurements is estimated to be $\pm 5 \%$ for each clay mineral. The illite crystallinity and the Esquevin index (Esquevin 1969) were measured on the XRD diagrams. The illite crystallinity (in ${ }^{\circ} 2 \theta$ ) corresponds to the full width at half maximum (measured on the illite peak at $10 \AA$ ). A high Kübler index indicates very low to low metamorphism, whereas low values reflect a high metamorphism. The Esquevin index corresponds to the ratio between the illite intensity measured at 5 and at $10 \AA$ and is used to evaluate the chemical composition of illite (Al-rich versus $\mathrm{Fe} / \mathrm{Mg}$ rich).

The quantity and quality of the organic matter (OM) were estimated by analysing the total carbon (TC), the total hydrogen (TH), the total nitrogen (TN) and the total sulphur (TS) contents in the surface sediment (Armynot du Châtelet et al. 2013). A FlashEA 1112 Elemental Analyser (Thermo) equipped with an autosampler was used. The analysis was performed on 1.5 to $2 \mathrm{mg}$ of sample added to approximately $5 \mathrm{mg}$ of vanadium pentoxide, used as a combustion catalyst. 2,5- Bis(5-tert-butyl-benzoxazol-2-yl) thiophene (BBOT) was used as standard. The organic carbon (Corg) content was then determined by subtracting carbonate carbon (total inorganic carbon, TIC) from TC. Calcium carbonate proportions were determined using a Bernard calcimeter and expressed as dry sediment weight. Measurements were carried out on triplicate for each station with $1 \mathrm{~g}$ of finely crushed dry sediment. Measurements were carried out in duplicate on each sample and a mean was calculated after checking that there were no dissimilarities. 


\section{Benthic assemblage analyses}

In the laboratory, samples were rinsed with a gentle jet of fresh water through a 0.5$\mathrm{mm}$ sieve to separate the macrobenthos from the meiobenthos (Danovaro et al. 2004). They were then decanted, sieved ten times through a $38-\mu \mathrm{m}$ mesh and centrifuged three times with Ludox HS30 (specific density 1.18, McIntyre and Warwick 1984). The meiobenthic organisms were counted and identified at the major taxon level using a stereomicroscope (Leica G26). The density $(10 \mathrm{~cm}-2)$ and the richness of the meiobenthic assemblage were calculated. In accordance with Moreno et al. (2011), 100 nematode individuals from each replicate were randomly picked up, transferred in glycerine and mounted as permanent slides (Seinhorst 1959). Identification at the genus level was performed using a light optical microscope equipped with Nomarski optics (Optiphoto-2 Nikon), with the support of pictorial keys (Platt and Warwick 1983, 1988; Warwick et al. 1998) and the NeMys online identification key (Vanaverbeke et al. 2015).

The Shannon $\left(\mathrm{H}^{\prime}\right)$ and Pielou $\left(\mathrm{J}^{\prime}\right.$, both $\left.\log 2\right)$ indices were calculated on the data collected from nematode assemblages, in order to provide a measure of the taxonomic biodiversity. Nematode genera were classified according to Wieser (1953) into four feeding groups to investigate the trophic structure of the assemblages: selective (1A) and non selective (1B) deposit feeders, epistrate feeders (2A) and omnivores/carnivores (2B). Accordingly, the index of trophic diversity (ITD), based on the proportion of each trophic group, was calculated following Heip et al. (1985). Since an environmental disturbance may change the food supply in a given area, an increase of ITD values, due to a marked dominance of a single trophic group, may be indicative of a stress increase. After Bongers et al. (1991), maturity index (MI) was determined for the nematode assemblage as the weighted average of the individual coloniser-persister (c-p) species. In particular, the authors distinguished rstrategist species (colonisers or c-p 1), which are more tolerant of environmental variations, and k-strategist species (persisters or c-p 5) that are more sensitive. This index has been proposed as a semi quantitative value that is useful when it comes to revealing ecosystem conditions from the composition analysis of the nematode assemblage.

The EQS of the study area was defined according to Marin et al. (2008) for the environmental variables and to Danovaro et al. (2004) (modified in accordance with the ecological quality (EcoQ) classes of the WFD) for the meiobenthos, while the thresholds suggested by Moreno et al. (2011) and Semprucci et al. (2014a, b) were used to assess the EQS using the nematodes (Table 1). 


\section{Statistical analysis}

Non-metric multi-dimensional scaling (nMDS) ordinations derived from Bray-Curtis similarity matrices were used to check differences in the structure of the meiobenthic assemblages between the sites and the seasons (fourth root transformation). The significance of these differences was tested using an analysis of similarities (2-way crossed ANOSIMsite ${ }^{\circ}$ - season). Both the analyses have been also used to detect possible differences in the trophic and c-p structure of the nematode assemblages. A similarity percentage (SIMPER) test (cut-off of $50 \%$ ) was used to determine the contribution of each taxon to the total dissimilarity. All analyses were performed using the Primer v.5 software package (Clarke and Gorley 2001; Clarke and Warwick 2001). Possible significant differences in all the univariate measures were evaluated using an analysis of variance (2-way ANOVA site ${ }^{\circ}$ season). Prior to analysis, the normality and homoscedasticity assumptions were checked using the Kolmogorov-Smirnov and Levene's tests, respectively. When required, the data were $\log (1+\mathrm{x})$ transformed. Tukey's multiple comparison tests were applied when significant differences $(\mathrm{p}<0.05)$ were detected (SPSS v.17 program).

Principal component analysis (PCA) was carried out on the more relevant environmental data in order to visualise the spatial and temporal trends of the environmental variables. In particular, the relative abundances of the meiobenthic components were projected on the factor plane as additional variables without contributing to the results of the analysis. This can provide an insight into the possible influence of the environmental variables upon each meiobenthic group (STATISTICA v.8 computer program). All the data were $\log (1+\mathrm{x})$ transformed prior to the PCA analysis, and only the taxa with a relative abundance overall exceeding $1 \%$ were taken into consideration.

\section{Results}

The physical and chemical variables of the water column and sediment as well as clay mineralogy are synthetically reported in Table 2. Both sediment and water environmental parameters showed a clear temporal variation, especially Chl-a, temperature, salinity, $\mathrm{O} 2 \%$, $\mathrm{pH}$, mud, sand and Corg. In particular, Chl-a showed levels that suggested 'alerting' conditions at FI and FO during N11.

The sediments were regarded as fine sands characterised by a clear dominance of sand (66.9\%, on average) followed by silt (32.9\%) and clay $(0.2 \%)$, with the exception of site FI (J12) in which the silt was the dominant fraction (61.2\%), followed by sand (38.1\%) and clay $(0.7 \%)$. All samples were characterised by the dominance of smectite (Table 2), which 
represented on average $54 \%$ of the clay fraction. Illite $(25 \%)$ and chlorite (13\%) were secondary minerals, while kaolinite was less abundant ( $8 \%$, on average). The crystallinity (Kübler index) was rather good, ranging between 0.25 and $0.30^{\circ} 2 \theta$, suggesting that the parent rock underwent a moderate metamorphism (anchizone). The Esquevin index ranges between 0.19 and 0.26 and indicates that the illite was mainly produced through physical erosion.

Meiobenthos was characterised by 15 taxonomic groups (Table 3). The values of the taxonomic richness ranged between 8 (FI and FO) and $10(\mathrm{M})$ taxa during N11 and between 9 (FI) and 12 (M) taxa during J12. Applying the EcoQ classification based on this meiobenthic variable, the study area falls within the EcoQ classes from poor (FI and FO N11) to sufficient (other stations and periods) (Fig. 2). The average abundances of meiofauna ranged between 874.7 \pm 688.2 and $2573.8 \pm 1112.4$ ind. $10 \mathrm{~cm}-2$ during N11 (B and M, respectively) and between $1111.3 \pm 77.9$ and $4043.6 \pm 1714.0$ ind. $10 \mathrm{~cm}-2$ during J12 (FI and M, respectively).

Overall, nematodes accounted for $90 \%$ of the total meiofauna during J12

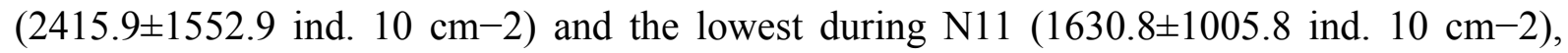
followed by Platyhelminthes (5\%), copepods (adults and nauplii) (2\%), foraminifera (2\%), gastrotrichs and ostracods (1\%) (Fig. 3). All other meiofaunal taxa (rotifers, nemertines, polychaetes, oligochaetes, bivalves, amphipods, isopods, cumaceans and mites) accounted for less than $1 \%$ of the assemblage. between the two periods $(\mathrm{R}=0.80 ; \mathrm{p}<0.001)$ rather than between the sites $(\mathrm{R}=0.32 ; \mathrm{p}<0.001)$. This pattern of distribution was well marked in the nMDS plot (Fig. 4a, b). The greatest dissimilarities were revealed between FI versus M $(\mathrm{R}=0.69 ; \mathrm{p}<0.02)$ and $\mathrm{FI}$ versus $\mathrm{B}(\mathrm{R}=0.46 ; \mathrm{p}<0.01)$, followed by FI versus $\mathrm{FO}(\mathrm{R}=0.41$; $\mathrm{p}<0.01)$ and $\mathrm{FO}$ versus $\mathrm{M}(\mathrm{R}=0.24 ; \mathrm{p}<0.03)$. SIMPER test (cut-off, $50 \%$ ) revealed that a lower abundance of all meiobenthic taxa was generally recorded at FI with the exception of nematodes. Higher abundances of nauplii and gastrotrichs at FI were only recorded in the FI versus FO comparison. All the taxa resulted to be less abundant in the comparison of FO versus M. Regarding the dissimilarities between the periods, they resulted mainly due to higher abundances of all the taxa during J12 (SIMPER test, cut-off $50 \%$ ). The only exception to this trend was rotifer taxon, more abundant during N11. PCA was performed to evaluate the potential influence of the environmental parameters on the assemblages. The first two factors of the PCA explained 86\%of the variance (PC1 $72 \%$, PC2 $14 \%$; eigenvalues 5.8 and 1.1, respectively) (Fig. 4a, b). The variables that contribute the most to PC1 were Chl-a $(+0.98)$, temperature $(-0.97)$, salinity $(-0.93)$ and $\mathrm{O} 2 \%(+0.93), \mathrm{pH}(-0.91)$, mud $(-0.83)$ and sand $(+0.77)$, while Corg $(-0.98)$ showed the greatest influence in the PC2. Among the meiobenthic components that were most related to the PC1 variables, the most abundant were 
foraminifera $(-1.79)$, ostracods $(-1.06)$, platyhelminthes $(+0.79)$, gastrotrichs $(-0.63)$ and nematodes $(-0.60)$. Nematodes and copepods appeared to be more influenced by the second factor plan (+0.39) (Fig. 5a, b).

The nematode assemblage was represented by 64 genera in 22 families (Table 4). The dominant families were Xyalidae (42.6\%), followed by Chromadoridae (14.6\%), Comesomatidae (13.2\%) and Axonolaimidae (11.9\%). The 2-way ANOSIM revealed significant differences both between the sites $(\mathrm{R}=0.42 ; \mathrm{p}<0.001)$ and the periods $(\mathrm{R}=0.57$; $\mathrm{p}<0.001$ ), but they were more marked between the latter. This pattern was clearly shown also by the nMDS analysis (Fig. 6a, b). From the results of the pair-wise comparisons, the highest differences were detected in the comparison of $\mathrm{B}$ versus FO $(\mathrm{R}=0.80 ; \mathrm{p}<0.01)$, followed by FI versus $F O(R=0.65 ; p<0.01), M$ versus $F O(R=0.33 ; p<0.05)$, $M$ versus $F I(R=0.33 ; p<0.05)$ and FI versus $B(R=0.24 ; \mathrm{p}<0.05)$. The genera representing $50 \%$ of the nematode assemblage were Daptonema, Sabatieria, Tricotheristus, Odontophora and Cobbia at site FI; Daptonema, Dichromadora, Odontophora, Tricotheristus, Sabatieria and Prochromadorella at B site; Odontophora, Daptonema, Sabatieria and Cobbia at FO site; and Daptonema, Cobbia, Odontophora, Prochromadorella, Dichromadora and Theristus at M site (SIMPER, 50 \%). In particular, the nematode genera that mainly contributed to distinguish FO assemblages were Paramonohystera, Stylotheristus, Oncholaimellus and Viscosia, all of them being more abundant there. Instead, Anticoma, Stylotheristus, Viscosia and Theristus contributed to the differences between FI and the other sites (SIMPER, 50\%). $\mathrm{H}^{\prime}$ index showed values between $3.46 \pm 0.10$ (B, N11) and 3.00 \pm 0.03 (FO, J12), while $\mathrm{J}^{\prime}$ index ranged between $0.83 \pm 0.09$ (B and $\mathrm{M}, \mathrm{N} 11)$ and $0.75 \pm 0.09$ (FI, N11 and FO, J12). Both these diversity indices have not revealed significant differences in the temporal and spatial comparisons (ANOVA, $\mathrm{p}>0.05$ ). MI exhibited the highest values at M J12 (2.29 \pm 0.11$)$ and the lowest at FI N11 (2.09 \pm 0.02$)$. However, it did not show significant differences between the analysed factors (ANOVA, $\mathrm{p}>0.05$ ). Overall, the dominant coloniser-persister class was the c-p 2 (on average $82 \%$ ), followed by c-p 3 (17\%), c-p 4 (1\%) and c-p 1 (0.1\%). ANOVA detected significant differences of the c-p 1 between sites $(F=3.77, p<0.05)$ and in the site ${ }^{\circ}$ - season interaction $(F=3.77, p<0.05)$. This was due to the presence of the c-p 1 only at the FO site during N11 (Fig. 7). The highest percentage of c-p 2 was found at FI N11 (91\%) while the lowest at M J12 (74 \%), but no significant difference was found (ANOVA). The c-p 3 class showed the highest abundances at M J12 (23\%) and the lowest at FI N11 (7.9\%). ANOVA detected significant differences only between the sites $(\mathrm{F}=4.19, \mathrm{p}<0.05)$. In detail, Tukey's test showed significant differences between sites $\mathrm{M}$ versus FI with the highest values detected in the 
former site. The class c-p 4 was more abundant at Mand B, J12 (2.9 and 0.3\%, respectively), but no significant difference was revealed (ANOVA). Considering the structure of the assemblage in view of the species life strategies, no significant difference was detected by ANOSIM. From a trophic point of view, the nematode assemblage was mainly represented by group 1B (60\%), followed by 2A (35\%), 1A (3\%) and 2B (2\%) (Fig. 8). The 1A group ranged from $0.3 \%(\mathrm{~B}, \mathrm{~N} 11)$ to $7 \%(\mathrm{FI}, \mathrm{N} 11), 1 \mathrm{~B}$ from $31 \%(\mathrm{M}, \mathrm{N} 11)$ to $77 \%(\mathrm{FO}, \mathrm{J} 12), 2 \mathrm{~A}$ from $16 \%$ (FI, N11) to $66 \%(\mathrm{M}, \mathrm{N} 11)$ and $2 \mathrm{~B}$ from $0.3 \%$ (FO and $\mathrm{M}, \mathrm{J} 12)$ to $3 \%$ (FO and $\mathrm{B}, \mathrm{N} 11)$. The $1 \mathrm{~A}$ revealed a significant difference between sites $(\mathrm{F}=6.19, \mathrm{p}<0.01)$ and, in particular, in FI versus B comparison (Tukey's test $\mathrm{p}<0.01$ ). The $1 \mathrm{~B}$ was significantly different both between sites $(F=5.64, p<0.01)$ and periods $(F=11.42, p<0.01)$. Also the season $\mathrm{x}$ site interaction showed significant differences $(\mathrm{F}=3.44, \mathrm{p}<0.05)$. The $2 \mathrm{~A}$ guild showed a similar trend with significant differences between sites $(\mathrm{F}=16.33, \mathrm{p}<0.001)$, periods $(\mathrm{F}=14.13$, $\mathrm{p}<0.01)$ as well as in the season ${ }^{\circ}$ - site interaction $(\mathrm{F}=9.36, \mathrm{p}<0.01)$. In particular, $2 \mathrm{~A}$ showed the highest values at M and B sites during N11 (Tukey's test $p<0.01$ and $p<0.05$, respectively). ITD showed values from $0.47 \pm 0.03$ (B, N11) to $0.64 \pm 0.11$ (FO, J12) but no significant differences (ANOVA, $\mathrm{p}>0.05$ ). The 2-way ANOSIM detected significant differences of the trophic structure of the assemblage only between the stations $(\mathrm{R}=0.25$; $\mathrm{p}<0.01)$. In detail, pair-wise comparisons revealed significant differences only between FI versus $B(R=0.50 ; p<0.05)$ and FI versus $M(R=0.65 ; p<0.05)$ that were due to the higher abundance of $1 \mathrm{~A}$ and $2 \mathrm{~B}$ at FI. When the nematode parameters were plotted in the PCA factor plain as secondary variables, only Southernia appeared clearly affected by the PC1 $(-0.78)$, followed by Chromadorina (-0.40), MI (-0.35), c-p $1(+0.35)$, Microlaimus $(+0.34)$ and Paracanthonchus (+0.32) (Fig. 5c). The nematode descriptors more affected in the PC2 were Theristus (+ 0.48), Tricotheristus (-0.48), Viscosia (-0.45), 2A (0.37), 1B (-0.34), Stylotheristus (-0.34), MI (0.31) and Dichromadora (0.31). Finally, applying the EcoQ classification based on the nematode assemblage, the study area fell within the EcoQ classes from poor to bad (Fig. 2).

\section{Discussion}

The European directives (WFD and MSFD) are the umbrella regulations for water systems, and the challenge for the scientific community is to translate their principles into realistic and accurate approaches (Van Hoey et al. 2010). Seafloor integrity should be at a level that ensures the ecosystems' structure and functions to be safeguarded, and benthic ecosystems should not be adversely affected. Among the descriptors of a good environmental 
status, there are the meiobenthic assemblages that may reflect a great variety of phenomena occurring into the seabed habitats (Vanaverbeke et al. 2011).

On the basis of the PCA plot, the riverine runoff, related to the seasonality, exerted the major impact on the study area (PC1). In particular, the Chl-a was the most important environmental variable in the study area along with temperature, salinity and $\mathrm{O} 2 \%$. The river discharge of nutrients to the sea was probably responsible of the microalgal bloom and subsequent Chl-a peak that could be interpreted as an evidence of eutrophication phenomena occurring during N11. This hypothesis is also supported by the low levels of salinity (freshwater inputs) recorded during this period, particularly at FO and FI. Furthermore, the occurrence of low-salinity waters both in the sampling point and off the site of FI could suggest the influence of the Po River plume. Indeed, the coastal circulation of the Adriatic Sea transports the waters northward, while the general thermohaline currents in the western Adriatic Sea flow southward (see Semprucci et al. 2010 for details). Accordingly, Tavollo River cannot exert an influence on FI, and Foglia River was not the source of the disturbance at the same site because its flow is not strong enough to reach FI (Semprucci et al. 2013a).

The clay mineralogy of the studied samples provides additional information concerning the main provenance of detrital particles as well as the possible disturbance sources. Clay mineral particles may originate from both coastal rivers and the Po River, which is a main contributor of the Adriatic Sea. The influence of coastal rivers may be important due to their high sediment contributions to the Adriatic Sea in spite of their relatively small watershed areas (Frignani et al. 1992; Milliman and Syvitski 1992; Sorgente 1999; Tomadin 2000). Previous studies revealed that Foglia and Metauro are enriched in smectite, which is further dispersed southeasternward along the coast. These smectite-rich sediments are likely transported to deeper parts of the basin as a consequence of turbidity processes (Franco et al. 1982; Tomadin 2000). By contrast, the Po River mainly carries illite and chlorite that basically result from physical erosion of the Alps (Chamley 1989). The clay mineral composition of the studied samples, dominated by smectite, indicates that coastal rivers are the main contributors to clay sedimentation in the studied area, with some secondary supply from the Po River as revealed by the presence of illite and chlorite. The crystallinity and chemical composition of the illite confirm that Po River was the main contributor (Fig. 9). The I/S ratio (Table 2) confirms that the coastal rivers were the dominant contributors near the coast ( $\mathrm{I} / \mathrm{S}=0.48$ on average) because the Po River plume was characterised by higher $\mathrm{I} / \mathrm{S}$ ratio up to 3.5 (Combourieu-Nebout et al. 2013). Indeed, the highest observed I/S ratio of 0.57 
(just above the mean \pm standard deviation) suggests a slightly stronger influence of the Po river versus local supply at FI during N11.

In the study area, eutrophication and mucilaginous events that correlated to the Po plume have been already documented by Penna et al. (2004). Worthy of note is that the Chl-a levels recorded during N11 can classify this area as in 'alerting' status of EcoQ in accordance with Marin et al. (2008). However, the discharge of other harmful products with the riverine inflows could exert a possible synergistic effect as reported by Semprucci et al. (2010). Considering the second factor plain (PC2, Corg) of PCA, it was clear that the relatively higher levels of OM were mainly in relation to FI and FO during N11, followed by the same stations during $\mathrm{J} 12$.

Applying the classification of EcoQ based on the taxonomic richness of meiofauna (Danovaro et al. 2004), the study area showed the worst EcoQ classes at FI and FO during N11. The statistical analysis carried out on the structure of the meiobenthic assemblages highlighted a greater dissimilarity of assemblage structures in relation to the sampling periods supporting the relevant effects of Po and Foglia rivers also on the meiobenthos. The effects of the Po plume on the meiobenthic assemblages until the coastal sediments of the Central Adriatic Sea have been previously documented by Danovaro et al. (2000). Indeed, these authors highlighted a change of abundance, richness and structure of the meiobenthic assemblage due to the Po plume inputs that enhanced the phytodetritus accumulation and benthic prokaryote response. The authors, however, documented an influence of the Po River at deeper stations (from 15 to $60 \mathrm{~m}$ ), while according to our results, the disturbance might be even closer to the coasts.

The meiobenthic taxa that were largely affected by seasonality were foraminifera and ostracods (both negatively) and platyhelminthes (positively). This finding is in agreement with the inverse relation reported in the literature between foraminifera, ostracod taxa and nutrients (Widbom and Elmgren 1988; Sundelin and Elmgren 1991; Gómez Noguera and Hendrickx 1997; Fabbrocini et al. 2005; Semprucci et al. 2013b). Platyhelminthes, generally a sensitive taxon (Frontalini et al. 2011), appeared probably more related to the grain size of the sediment than to the Chl-a enhancement, being generally more abundant in sandy substrata (Martens and Schockaert 1986). All the meiobenthic taxa showed low abundances at FI and FO sites. An exception was the taxon Nematoda that distinguished FI with its high abundance. Nematodes are well known to persist in poor ecological conditions (Moreno et al. 2011; Balsamo et al. 2012). All of the meiobenthic taxa showed a negative correlation with Corg. This is in agreement with the available information on taxa such as copepods, which generally 
are more abundant in pristine habitats (Coull and Chandler 1992; Lee et al. 2001; McLachlan and Brown 2006; Ansari et al. 2013), but in contrast with the general trend observed for nematodes. However, the response of the nematode abundance to the sewage outfalls or organic enrichment does not always give unequivocal results (Sandulli and De Nicola-Giudici 1990, 1991; see Coull and Chandler 1992 for a review; Schratzberger and Warwick 1998; Fraschetti et al. 2006; Schratzberger et al. 2008; Armenteros et al. 2010).

In the study area, the most abundant families and genera of nematodes were the representatives of the assemblages of the northern and Central Adriatic Sea (Travizi and Vidakovic 1997; Semprucci 2013; Semprucci et al. 2010, 2013a), and they may be considered as typical iso-communities of muddy sediments (see Heip et al. 1985 for review). The overall level of biodiversity was highly comparable with that detected in previous studies in the area (Semprucci et al. 2010, 2013a). As for the meiobenthic assemblage, statistical analysis documented a higher difference between the periods than the sites, demonstrating that the riverine discharges affected also the structure of the nematode assemblages. It is worth noting that the meiobenthic assemblage seemed to give even a higher response to the riverine temporal impact with their taxa being more sensitive to the Chl-a enhancement. This could suggest that meiobenthos (at high taxonomic level) may be a good tool for the survey of a short-term response to eutrophication as highlighted also by Carriço et al. (2013). Thus, periodical surveys of the meiobenthos could be sufficient for detecting riverine impact being a great advantage for the easier and rapid study protocols compared to assemblages of single taxa studied at low taxonomic level. Instead, the greater differences in the nematode assemblage between sites may suggest that a low taxonomic level study can be more relevant for long-term responses to the human impact. The nematode assemblage was mainly characterised by Odontophora, Sabatieria and Daptonema that are well recognised as typical of fine or muddy sediments of the Adriatic coasts and are considered as successful opportunistic colonisers (Somerfield et al. 1994; Steyaert et al. 1999; Schratzberger et al. 2006; Hedfi et al. 2007; Moreno et al. 2009, 2011; Armenteros et al. 2009; Van Colen et al. 2009). In detail, the greatest dissimilarity of the assemblage structure was revealed at site FO and it was mainly due to the genera Paramonohystera, Stylotheristus, Oncholaimellus, Viscosia and Sabatieria. The genera Paramonohystera, Stylotheristus and, to a lesser extent, Cobbia (Xyalidae) have been previously well documented at Baia Flaminia, a disturbed site close to the harbour of Pesaro (Semprucci et al. 2013a), and also at the FO mouth where the level of disturbance was discernible (Semprucci et al. 2010). The genus Oncholaimellus is reported in the literature both as opportunistic and sensitive (Danovaro et al. 1995; Hedfi et al. 
2007; Mahmoudi et al. 2007; Beyrem et al. 2011; Moreno et al. 2011); therefore, its use as a bioindicator of contamination may sometimes be problematic (Losi et al. 2013), as well as that of the genus Oncholaimus. This is because Oncholaimidae combine characteristics of persisters (low reproductive potential, long generation time, few eggs) and colonisers (occurrence in eutrophicated and heavily stressed conditions) (Bongers et al. 1991). In the present study, Oncholaimellus did not show any correlation with Corg\%, but an inverse trend to $\mathrm{O} 2 \%$ has been observed. A more consistent response of another Oncholaimidae genus, Viscosia, was observed. This genus, mainly found in the disturbed FO and FI sites, is reported in the literature as a taxon tolerant to hydrocarbons, heavy metals and organic enrichment even related to eutrophication events (e.g. Danovaro et al. 1995; Beyrem et al. 2011; Carriço et al. 2013; Semprucci et al. 2013a). Viscosia resulted, in fact, particularly related to Corg\% along with the non-selective deposit feeders Stylotheristus, Tricotheristus and Daptonema (Xyalidae). Instead, the genera that mainly contributed to distinguish FI for abundance were Anticoma, Stylotheristus, Viscosia and Theristus, all generally considered from highly to moderate tolerant groups (Millward and Grant 1995; Gyedu-Ababio et al. 1999; Moreno et al. 2008, 2011).

Considering the PCA results, only Microlaimus and Paracanthonchus seemed slightly positively related to the $\mathrm{Chl}-\mathrm{a}$ increase: Microlaimus was reported by some authors as tolerant to hydrocarbon and metal contamination (Gyedu-Ababio and Baird 2006; Van Gaever et al. 2009; Losi et al. 2013), but Moreno et al. (2011) documented a general sensitivity of this genus in the Mediterranean Sea shallow coasts. In contrast, the genus Southernia was the only clearly negatively correlated to the Chl-a, probably related to its affinities with mud in which, as selective deposit feeders, may find a high trophic resource like bacteria (Heip et al. 1985; Warwick et al. 1998); a sensitive reaction to the Chl-a may be also inferred. At B and M sites, the percentages of Odontophora, Sabatieria and Daptonema were notable, but an enhancement of the Chromadoridae and Cyatholaimidae may be detectable. They can be considered from moderate opportunistic to sensitive taxa (Boucher 1980; Moreno et al. 2011), and their relative opposite position with respect to the Corg could confirm this behaviour.

Biological traits seemed to perfectly summarise the ecological conditions of the study area and even clearly than the taxonomic structure of the nematode assemblage could do. Indeed, c-p 1 (extreme coloniser species) and c-p 2 (general coloniser species) seemed positively correlated to the Chl-a and Corg, respectively. Bongers et al. (1991) reported their high abundance in stressed habitats and in particular under eutrophic conditions, which is in line with their higher percentages during N11 and especially in the FI and FO sites. MI as 
well as the class c-p 3 (intermediate coloniser species) and c-p 4 (persistent species) revealed an opposite trend compared to both Chl-a and Corg showing that the life strategy of nematodes may be greatly influenced by the riverine inflows. In contrast, ITD did not show any type of correlation so confirming, as suggested by Moreno et al. (2011) and Alves et al. (2013), that it is a useless index to detect the anthropogenic impact on the benthic assemblages. The single trophic groups seemed more informative than ITD: 2A was more related to the sand fraction and especially negatively affected by organic matter, while deposivours (1A+1B) followed the Corg enhancement (see Semprucci and Balsamo 2012 for review). The $2 \mathrm{~B}$ seemed to follow this last parameter, but it was probably related to the ability of Oncholaimidae, as facultative predators, to take advantage also of detritus deposits (Moens and Vincx 1997). No relevant information was given by the diversity indices neither by ANOVA nor by PCA results. Applying the classification of EcoQ based on the thresholds suggested by Moreno et al. (2011) and integrated by Semprucci et al. (2014a, b), the study area falls within the EcoQ classes from poor to bad, highlighting the same trends observed in the meiobenthic assemblages.

\section{Conclusions}

The present study documents that both the meiobenthic and the nematode assemblages were affected by human disturbance and that impact was mainly due to the local streams and secondly by Po plume. Po River influence has been already documented on the benthic assemblages of the Central Adriatic Sea, though at greater depths. In contrast, the present investigation clearly demonstrates that Po plume may also exert a disturbance on the benthic assemblages at a closer distance from the coasts. Applying the thresholds that are currently suggested for the meiobenthic and nematode assemblages, the study area falls within the EcoQ classes from poor to sufficient and from poor to bad using meiobenthos and nematodes, respectively. Meiobenthic and nematode assemblages seem also to respond in a different way to disturbance. The former could be used in the biomonitoring assessment as a good tool for detecting short-term responses of the benthic domain, especially in comparison with nematode assemblage that seems to give a long-term response. When single descriptors are analysed to find the best ones, life strategy traits appeared the most informative tool showing a high correspondence with the environmental variables and particularly with stressors.

\section{References}


Alves, A. S., Adão, H., Ferrero, T. J., Marques, J. C., Costa, M. J., \& Patrício, J. (2013). Benthic meiofauna as indicator of ecological changes in estuarine ecosystems: the use of nematodes in ecological quality assessment. Ecological Indicators, 24, 462-475.

Ansari, K. G.M. T., Lyla, P. S., Ajmal Khan, S., Manokaran, S., \& Raja, S. (2013). Community structure of harpacticoid copepods from the southeast continental shelf of India. Proceedings of the International Academy of Ecology and Environmental Sciences, 3, 87100.

Armenteros, M., Ruiz-Abierno, A., Fernández-Garcés, R., Pérez- García, J. A., DíazAsencio, L., Vincx, M., \& Decraemer,W. (2009). Biodiversity patterns of free-living marine nematodes in a tropical bay: Cienfuegos, Caribbean Sea. Estuarine Coastal Shelf Science, 85, 179-189.

Armenteros, M., Pérez-García, J. A., Ruiz-Abierno, A., Díaz- Asencio, L., Helguera, Y., Vincx, M., \& Decraemer, W. (2010). Effects of organic enrichment on nematode assemblages in a microcosm experiment. Marine Environmental Research, 70, 374-382.

Armynot du Châtelet, E., Bout-Roumazeilles, V., Coccioni, R., Frontalini, F., Guillot, F., Kaminski, M. A., Recourt, P., Riboulleau, A., Trentesaux, A., Tribovillard, N., \& Ventalon, S. (2013). Environmental control on shell structure and composition of agglutinated foraminifera along a proximal- distal transect in the Marmara Sea. Marine Geology, 335, $114-128$.

Artegiani, A., Bregant, D., Paschini, E., Pinardi, N., Raicich, F., \& Russo, A. (1997). The Adriatic Sea general circulation, part I: baroclinic circulation structure. Journal of Physical Oceanography, 27, 1515-1532.

Balsamo, M., Albertelli, G., Ceccherelli, V. U., Coccioni, R., Colangelo, M. A., CuriniGalletti, M., Danovaro, R., D’Addabbo, R., Leonardis, C., Fabiano, M., Frontalini, F., Gallo, M., Gambi, C., Guidi, L., Moreno, M., Pusceddu, A., Sandulli, R., Semprucci, F., Todaro, M. A., \& Tongiorgi, P. (2010). Meiofauna of the Adriatic Sea: current state of knowledge and future perspectives. Chemistry and Ecology, 26, 45-63.

Balsamo, M., Semprucci, F., Frontalini, F., \& Coccioni, R. (2012). Meiofauna as a tool for marine ecosystem biomonitoring. In A. Cruzado (Ed.), Marine ecosystems (pp. 77-104). Rijeka: InTech.

Beyrem, H., Boufahja, F., Hedfi, A., Essid, N., Aïssa, P., \& Mahmoudi, E. (2011). Laboratory study on individual and combined effects of cobalt- and zinc-spiked sediment on meiobenthic nematodes. Biological Trace Elements Research, 144, 790-803. 
Bongers, T., \& Van de Haar, J. (1990). On the potential of basing an ecological typology of aquatic sediments on the nematode fauna: an example from the river Rhine. Hydrobiology Bulletin, 24, 37-45.

Bongers, T., Alkemade, R., \& Yeates, G.W. (1991). Interpretation of disturbance-induced maturity decrease in marine nematode assemblages by means of the maturity index. Marine Ecology Progress Series, 76, 135-142.

Borja, A., \& Dauer, D. M. (2008). Assessing the environmental quality status in estuarine and coastal systems: comparing methodologies and indices. Ecological Indicators, 8, 331-337.

Borja, Á., Franco, J., \& Pérez, V. (2000). A marine biotic index to establish the ecological quality of soft-bottom benthos within European estuarine and coastal environments. Marine Pollution Bulletin, 12, 1100-1114.

Boucher, G. (1980). Facteurs d'equilibre d'un peuplement de nematodes libres des sables sublittoraux. Mémoires du .... Museum national d'Histoire Naturelle, Paris, 114, 1-81.

Bout-Roumazeilles, V., Combourieu-Nebout, N., Desprat, S., Siani, G., Turon, J.-L., \& Essallami, L. (2013). Tracking atmospheric and riverine terrigenous supplies variability during the last glacial and the Holocene in central Mediterranean. Climate of the Past Discussions, 9, 1065-1087.

Carriço, R., Zeppilli, D., Quillien, N., \& Grall, J. (2013). Can meiofauna be a good biological indicator of the impacts of eutrophication caused by green macroalgal blooms? An Ado Les Cahiers Naturalistes De 1'Observatoire Marin, 2, 9-16.

Chamley, H. (1989). Clay sedimentology. Berlin: Springer.

Clarke, K. R., \& Gorley, R. N. (2001). Primer version 5. Plymouth: Primer-E.

Clarke, K. R., \& Warwick, R. M. (2001). Change in marine communities: an approach to statistical analysis and interpretation (2nd ed.). Plymouth: Primer-E.

Combourieu-Nebout, N., Peyron, O., Bout-Roumazeilles, V., Goring, S., Dormoy, I., Joannin, S., Sadori, L., Siani, G., \& Magny, M. (2013). Holocene vegetation and climate changes in the central Mediterranean inferred from a high-resolution marine pollen record (Adriatic Sea). Climate of the Past Discussions, 9, 1669-2014.

Coull, B. C., \& Chandler, G. T. (1992). Pollution and meiofauna: field, laboratory and mesocosm studies. Oceanography and Marine Biology: An Annual Review, 30, 191-271.

Danovaro, R., Fabiano, M., \& Vincx, M. (1995). Meiofauna response to the Agip Abruzzo oil spill in subtidal sediments of the Ligurian Sea. Marine Pollution Bulletin, 30, 133-145.

Danovaro, R., Gambi, C., Manini, E., \& Fabiano, M. (2000). Meiofauna response to a dynamic river plume front. Marine Biology, 137, 359-370. 
Danovaro, R., Gambi, C., Mirto, S., Sandulli, R., Ceccherelli, V.U. (2004). Meiofauna. In Mediterranean marine benthos: a manual of methods for its sampling and study. In M.C. Gambi, M. Dappiano (Eds), Biologia Marina Mediterranea, 11, 55-97.

Esquevin, J. (1969). Influence de la composition chimique des argiles sur la cristallinité. Bulletin du Centre de Recherches de Pau -S.N.P.A, 3, 147-154.

Fabbrocini, A., Guarino, A., \& Scirocco, T. (2005). Integrated biomonitoring assessment of the Lesina Lagoon (Southern Adriatic Coast, Italy): preliminary results. Chemistry and Ecology, 21, 479-489.

Franco, P., Jeftic, L., Malanotte Rizzoli, P., Michelato, A., \& Orlic, M. (1982). Descriptive model of the northern Adriatic. Oceanologica Acta, 5, 379-389.

Fraschetti, S., Gambi, C., Giangrande, A., Musco, L., Terlizzi, A., \& Danovaro, R. (2006). Structural and functional response of meiofauna rocky assemblages to sewage pollution. Marine Pollution Bulletin, 52, 540-548.

Frignani, M., Langone, L., Pacelli, M., \& Ravaioli, M. (1992). Input, distribution and accumulation of dolomite in sediments of the Middle Adriatic Sea. Rapport Commission International Mer Mediterranée, 33, 324.

Frontalini, F., Semprucci, F., Coccioni, R., Balsamo, M., Bittoni, P., \& Covazzi-Harriague, A. (2011). On the quantitative distribution and community structure of the meio and macrofaunal communities in the coastal area of the Central Adriatic Sea (Italy). Environmental Monitoring and Assessment, 180, 325-344.

Gallucci, F., Steyaert, M., \& Moens, T. (2005). Can field distributions of marine predacious nematodes be explained by sediment constraints on their foraging success? Marine Ecology Progress Series, 304, 167-178.

Gaudiano, A., Pizzagalli, C., Reggiani, M.C., Banini, L., Grassini, P. (1994). Valutazione dello stato di inquinamento del fiume Foglia mediante l'uso di indicatori biologici. Amministrazione di Pesaro e Urbino. Fano.

Gómez Noguera, G., \& Hendrickx, M. E. (1997). Distribution and abundance of meiofauna in a subtropical coastal lagoon in the south-eastern Gulf of California. Marine Pollution Bulletin, $34,582-587$.

Gyedu-Ababio, T. K., \& Baird, D. (2006). Response of meiofauna and nematode communities to increased levels of contaminants in a laboratory microcosm experiment. Ecotoxicology and Environmental Safety, 63, 443-450. 
Gyedu-Ababio, T. K., Furstenberg, J. P., Baird, D., \& Vanreusel, A. (1999). Nematodes as indicators of pollution: a case study from the Swartkops river system, South Africa. Hydrobiologia, 397, 155-169.

Hedfi, A., Mahmoudi, E., Boufahja, F., Beyrem, H., \& Aïssa, P. (2007). Effects of increasing levels of nickel contamination on structure of offshore nematode communities in experimental microcosms. Bulletin of Environmental Contaminant and Toxicology, 79, 345349.

Heip, C., Vincx, M., \& Vranken, G. (1985). The ecology of marine nematodes. Oceanography and Marine Biology: An Annual Review, 23, 399-489.

Karr, J. R. (1999). Defining and measuring river health. Freshwater Biology, 41, 221-234.

Kennedy, A. D., \& Jacoby, C. A. (1999). Biological indicators of marine environmental health: meiofauna a neglected benthic component? Environmental Monitoring and Assessment, 54, 47-68.

Lee, M. R., Correa, J. A., \& Castilla, J. C. (2001). An assessment of the potential use of the nematode to copepod ratio in the monitoring of metals pollution. The Chañaral case. Marine Pollution Bulletin, 42, 696-701.

Loizeau, J.-L., Arbouille, D., Santiago, S., \& Vernet, J.-P. (1994). Evaluation of a wide range laser diffraction grain size analyser for use with sediments. Sedimentology, 41, 353-361.

Losi, V., Ferrero, T. J., Moreno, M., Gaozza, L., Rovere, A., Firpo, M., Marques, J. C., \& Albertelli, G. (2013). The use of nematodes in assessing ecological conditions in shallow waters surrounding a Mediterranean harbour facility. Estuarine, Coastal and Shelf Science, 130, 1-13.

Mahmoudi, E., Essid, E., Beyrem, H., Hedfi, A., Boufahja, F., Vitiello, P., \& Aïssa, P. (2007). Individual and combined effects of lead and zinc of a free living marine nematode community: results from microcosm experiments. Journal of Experimental Marine Biology and Ecology, 343, 217-226.

Marin, V., Moreno, M., Vassalo, P., Vezzuli, L., \& Fabiano, M. (2008). Development of a multistep indicator-based approach (MIBA) for the assessment of environmental quality of harbours. ICES Journal of Marine Science, 65, 1436-1441.

Martens, P. M., \& Schockaert, E. R. (1986). The importance of turbellarians in the marine meiobenthos: a review. Hydrobiologia, 132, 295-303.

McIntyre, A. D., \& Warwick, R. M. (1984). Meiofauna techniques. In N. A. Holme \& A. D. McIntyre (Eds.), Methods for the study of marine benthos (pp. 217-244). Oxford: Blackwell. McLachlan, A., \& Brown, A. C. (2006). The ecology of sandy shores. Burlington: Academic. 
Milliman, J. D., \& Syvitski, J. P. M. (1992). Geomorphic/ tectonic control of sediment discharge to the ocean: the importance of small mountainous rivers. Journal of Geology, 100, $525-544$.

Millward, R. N., \& Grant, A. (1995). Assessing the impact of copper on nematode communities from a chronically metal enriched estuary using pollution-induced community tolerance. Marine Pollution Bulletin, 30, 701-706.

Moens, T., \& Vincx, M. (1997). Observations on the feeding ecology of estuarine nematodes. Journal of the Marine Biological Association of the UK, 77, 211-227.

Moens, T., Dos Santos, G. A. P., Thompson, F., Swings, J., Fonseca-Genevois, V., Vincx, M., \& De Mesel, I. (2005). Do nematode mucus secretions affect bacterial growth? Aquatic Microbial Ecology, 40, 77-83.

Moreno, M., Ferrero, T. J., Gallizia, I., Vezzulli, L., Albertelli, G., \& Fabiano, M. (2008). An assessment of the spatial heterogeneity of environmental disturbance within an enclosed harbour through the analysis of meiofauna and nematode assemblages. Estuarine, Coastal and Shelf Science, 77, 565-576.

Moreno, M., Albertelli, G., \& Fabiano, M. (2009). Nematode response to metal, PAHs and organic enrichment in tourist marinas of the Mediterranean Sea. Marine Pollution Bulletin, $58,1192-1201$.

Moreno, M., Semprucci, F., Vezzulli, L., Balsamo, M., Fabiano, M., \& Albertelli, G. (2011). The use of nematodes in assessing ecological quality status in the Mediterranean coastal ecosystems. Ecological Indicators, 11, 328-336.

Mosci, D., Pierboni, L., Valentini, A., Ceccarini, M., \& Balsamo, M. (2002). Osservazioni preliminari sul meiozoobenthos del Parco Naturale del Monte San Bartolo (Pesaro). Biologia Marina Mediterranea, 9, 629-631.

Penna, N., Cappellacci, S.,\& Ricci, F. (2004). The influence of the Po River discharge on phytoplankton bloom dynamics along the coastline of Pesaro (Italy) in the Adriatic Sea. Marine Pollution Bulletin, 48, 321-326.

Petschick, R. (2001). MacDiff v4.2.5 (Free Geological Software), GeologischPalaontologisches Institut, Universitat Frankfurt/ Main. available at: http://www.geol-pal.unifrankfurt.de/ Staff/Homepages/Petschick/classicsoftware.html\#MacDiff Accessed 2 Jul 2012. Platt, H. M., \& Warwick, R. M. (1980). The significance of free-living nematodes to the littoral ecosystem. In J. H. Price, D. E. G. Irvine, \&W. F. Farnham(Eds.), The shore environment: ecosystems. Vol. 2 (pp. 729-759). New York: Academic. 
Platt, H.M., \& Warwick, R.M. (1983). Free-living marine nematodes. Part I. British Enoplids. Synopses of the British fauna (new series) Vol. 28. Cambridge Univ. Press, Cambridge.

Platt, H.M. \& Warwick, R.M. (1988). Free-living marine nematodes. Part II. British chromadorids. Synopses of the British fauna (new series). Vol. 38. Brill, Leiden.

Sandulli, R., \& De Nicola-Giudici, M. (1990). Pollution effects on the structure of meiofaunal communities in the Bay of Naples. Marine Pollution Bulletin, 21, 144-153.

Sandulli, R., \& De Nicola-Giudici, M. (1991). Responses of meiobenthic communities along a gradient of sewage pollution. Marine Pollution Bulletin, 22, 463-467.

Schratzberger, M., \& Warwick, R. M. (1998). Effects of the intensity and frequency of organic enrichment on two estuarine nematode communities. Marine Ecology Progress Series, $164,83-94$.

Schratzberger, M., Bolam, S., Whomersley, P., \&Warr, K. (2006). Differential response of nematode colonist communities to the intertidal placement of dredged material. Journal of Experimental Marine Biology and Ecology, 334, 244-255.

Schratzberger, M., Forster, R. M., Goodsir, F., \& Jennings, S. (2008). Nematode community dynamics over an annual production cycle in the central North Sea. Marine Environmental Research, 66, 508-519.

Seinhorst,W. (1959).A rapid method for the transfer of nematodes from fixative to anhydrous glycerin. Nematologica, 4, 67-69.

Semprucci, F. (2013).Marine nematodes from the shallow subtidal coast of the Adriatic Sea: species list and distribution. International Journal of Biodiversity, 1, 1-9.

Semprucci, F., \& Balsamo, M. (2012). Key role of free-living nematodes in the marine ecosystem. In F. Boeri \& A. C. Jordan (Eds.), Nematodes: morphology, functions and management strategies (pp. 109-34). Hauppauge: NOVA Science.

Semprucci, F., Boi, P., Manti, A., Covazzi Harriague, A., Rocchi, M., Colantoni, P., Papa, S., \& Balsamo, M. (2010). Benthic communities along a littoral of the Central Adriatic Sea (Italy). Helgoland Marine Research, 64, 101-115.

Semprucci, F., Frontalini, F., Covazzi-Harriague, A., Coccioni, R., \& Balsamo, M. (2013a).Meio- and macrofauna in the marine area of the Monte St. Bartolo Natural Park (Central Adriatic Sea, Italy). Scientia Marina, 77, 189-199.

Semprucci, F., Moreno, M., Sbrocca, S., Rocchi, M., Albertelli, G., \& Balsamo, M. (2013b). The nematode assemblage as a tool for the assessment of marine ecological quality status: a case-study in the Central Adriatic Sea. Mediterranean Marine Science, 14, 48-57. 
Semprucci, F., Balsamo, M., \& Frontalini, F. (2014a). The nematode assemblage of a coastal lagoon (Lake Varano, Southern Italy): ecology and biodiversity patterns. Scientia Marina, 78, $579-588$.

Semprucci, F., Colantoni, P., Sbrocca, C., Baldelli, G., \& Balsamo, M. (2014b). Spatial patterns of distribution of meiofaunal and nematode assemblages in the Huvadhoo lagoon (Maldives, Indian Ocean). Journal of Marine Biological Association of the United Kingdom, 94, 1377-1385.

Simboura, N., \& Zenetos, A. (2002). Benthic indicators to use in ecological quality classification of Mediterranean soft bottoms marine ecosystems, including a new biotic index. Mediterranean Marine Science, 3, 77-111.

Somerfield, P. J., Gee, J. M., \& Warwick, R. M. (1994). Soft sediment meiofaunal community structure in relation to a long-term heavy metal gradient in the Fal estuary system. Marine Ecology Progress Series, 105, 79-88.

Sorgente, D. (1999). Studio della sedimentazione attuale e recente nel medio Adriatico attraverso l'uso di traccianti redioattivi. Ph.D. thesis, University of Bologna.

Steyaert, M., Garner, N., Gansbeke, D., \& Vincx, M. (1999). Nematode communities from the North Sea: environmental controls on species diversity and vertical distribution within the sediment. Journal of Marine Biological Association of the United Kingdom, 79, 253-264.

Sundelin, B., \& Elmgren, R. (1991). Meiofauna of an experimental soft bottom ecosystemeffects of macrofauna and cadmium exposure. Marine Ecology Progress Series, 70, 245- 255. Tomadin, L. (2000). Sedimentary fluxed and different dispersion mechanism of the clay sediments in the Adriatic Basin. Rendiconti Lincei: Scienze Fisiche e Naturalia, 9, 161-174.

Travizi, A., \& Vidakovic, J. (1997). Nematofauna in the Adriatic Sea: review and check-list of free-living nematode species. Helgolaender Meeresuntersuchungen, 51, 503-519.

Trentesaux, A., Recourt, P., Bout-Roumazeilles, V., \& Tribovillard, N. (2001). Carbonate grain-size distribution in hemipelagic sediments from a laser particle sizer. International Journal of Sediment Research, 71, 858-862.

Van Colen, C., Montserrat, F., Verbist, K., Vincx, M., Steyaert, M., Vanaverbeke, J., Herman, P. M. J., Degraer, S., \& Ysebaert, T. (2009). Tidal flat nematode response to hypoxia and subsequent macrofauna-mediated alterations of sediment properties. Marine Ecology Progress Series, 381, 189-197.

Van Gaever, S., Olu, K., Derycke, S., \& Vanreusel, A. (2009). Metazoan meiofaunal communities at cold seeps along the Norwegian margin: influence of habitat heterogeneity and evidence for connection with shallow-water habitats. Deep- Sea Research I, 56, 772-785. 
Van Hoey, G., Borja, A., Birchenough, S., Buhl-Mortensen, L., Degraer, S., Fleischer, D., Kerckhof, F., Magni, P., Muxika, I., Reiss, H., Schroder, A., \& Zettler, M. L. (2010). The use of benthic indicators in Europe: from the Water Framework Directive to the Marine Strategy Framework Directive. Marine Pollution Bulletin, 60, 2187-2196.

Vanaverbeke, J., Merckx, B., Degraer, S., \& Vincx, M. (2011). Sediment-related distribution patterns of nematodes and macrofauna: two sides of the benthic coin? Marine Environmental Research, 71, 31-40.

Vanaverbeke, J., Bezerra, T.N., Braeckman, U., De Groote, A., De Meester, N., Deprez, T., Derycke, S., Gilarte, P., Guilini, K., Hauquier, F., Lins, L., Maria, T., Moens, T., Pape, E., Smol, N., Taheri, M., Van Campenhout, J., Vanreusel, A., Wu, X., Vincx, M. (2015). NeMys: world database of free-living marine nematodes. http://nemys.ugent.be Accessed 12 Mar 2015.

Warwick, R.M., Platt, H.M., Somerfield, P.J. (1998). Free-living marine nematodes. Part III. British monhysterids. Synopses of the British fauna (new series), Vol. 53. E J Brill/Dr W Backhuys, Leiden. Field Studies Council, Shrewsbury, UK. Widbom, B., \& Elmgren, R. (1988). Response of benthic meiofauna to nutrient enrichment of experimental marine ecosystems. Marine Ecology Progress Series, 42, 257-268.

Wieser, W. (1953). Die beziehung zwischen mundhöhlengestalt, ernährungsweise und vorkommen bei freilebenden marinen nematoden. Eine ökologisch-morphologische studie. Arkiv for Zoologica, 4, 439-484.

\section{Figure captions}




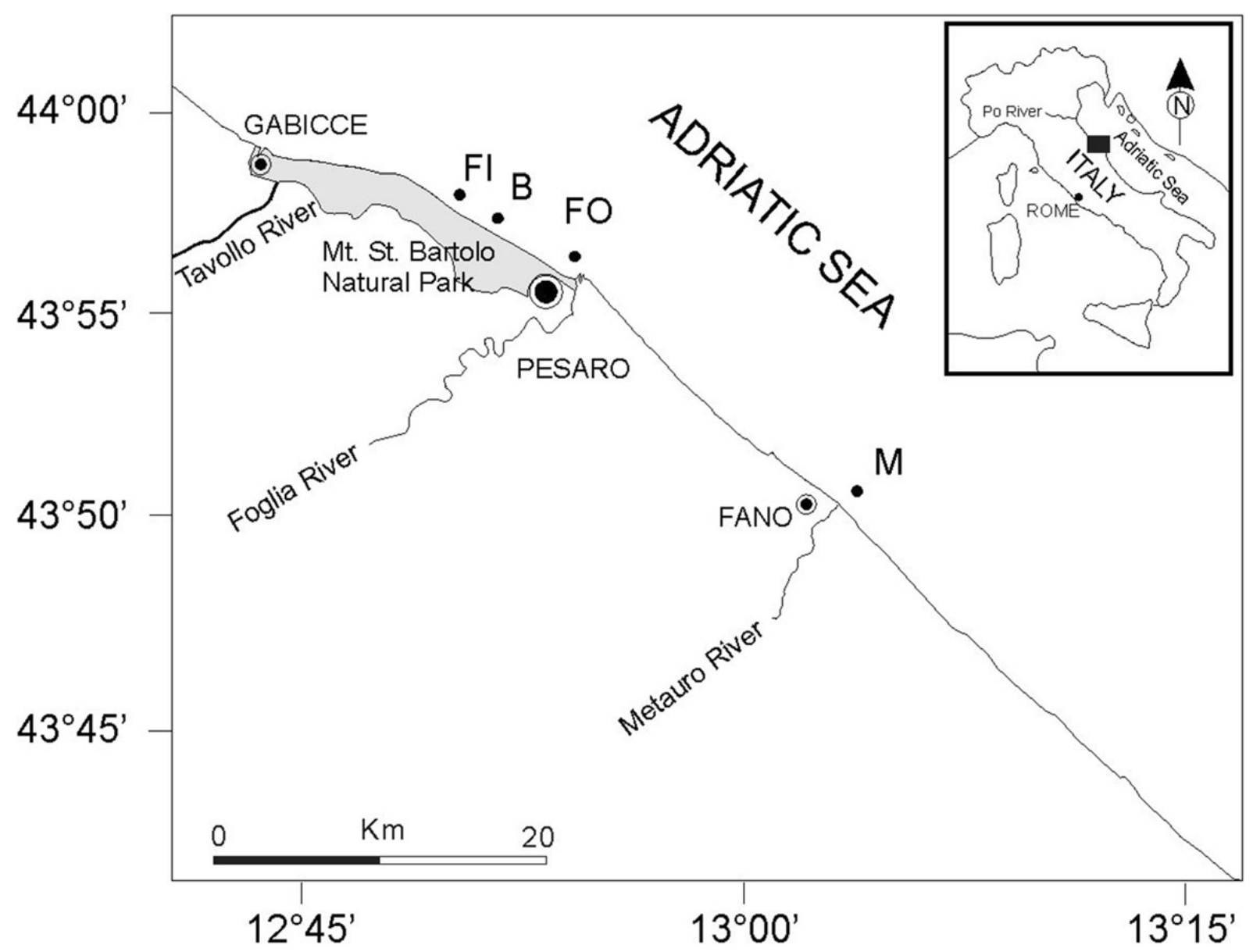

Fig. 1 Map of the study area and sampling stations 

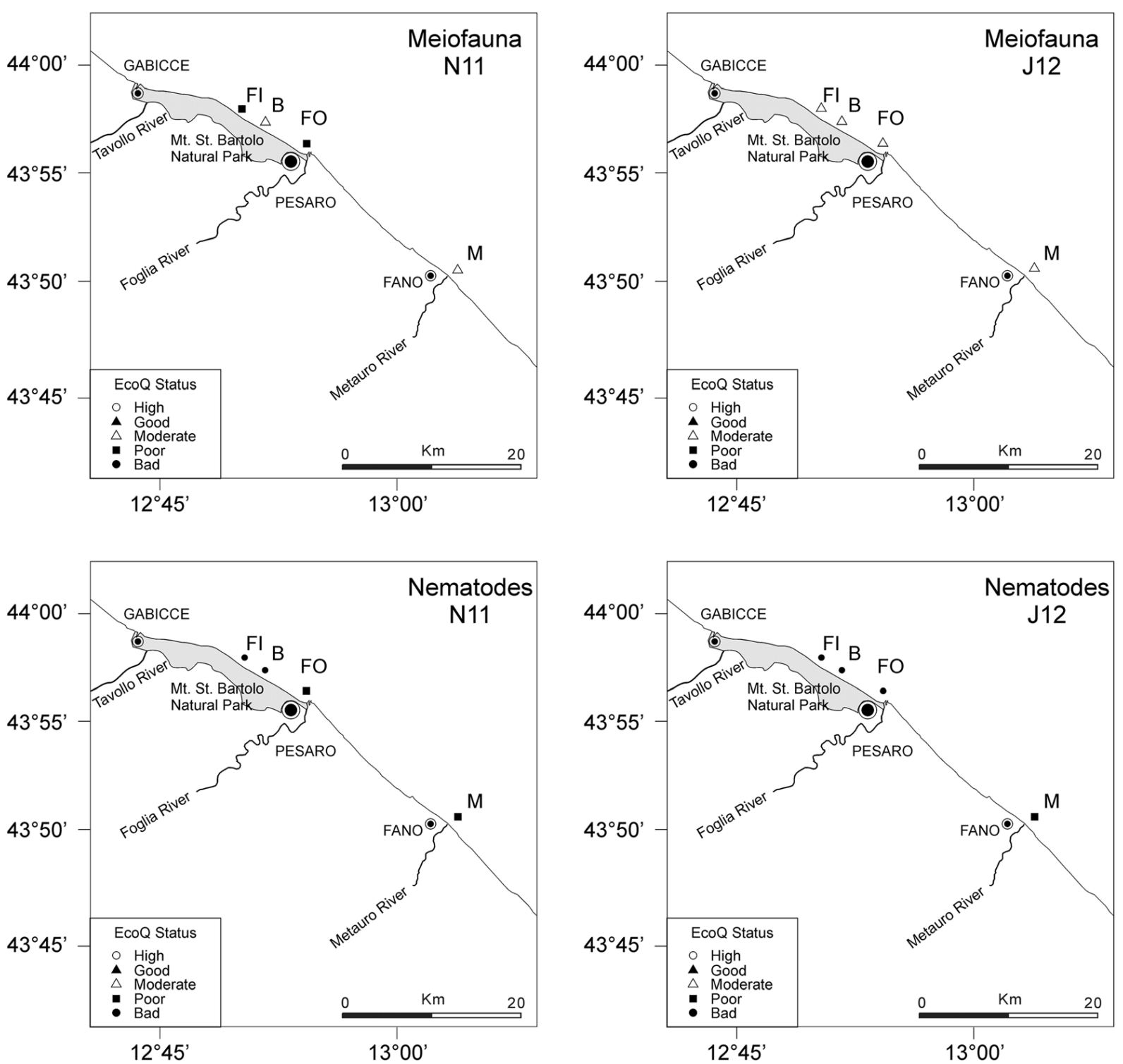

Fig. 2 Classification of the ecological quality (EcoQ) status of the study area using meiobenthos and nematode assemblages 


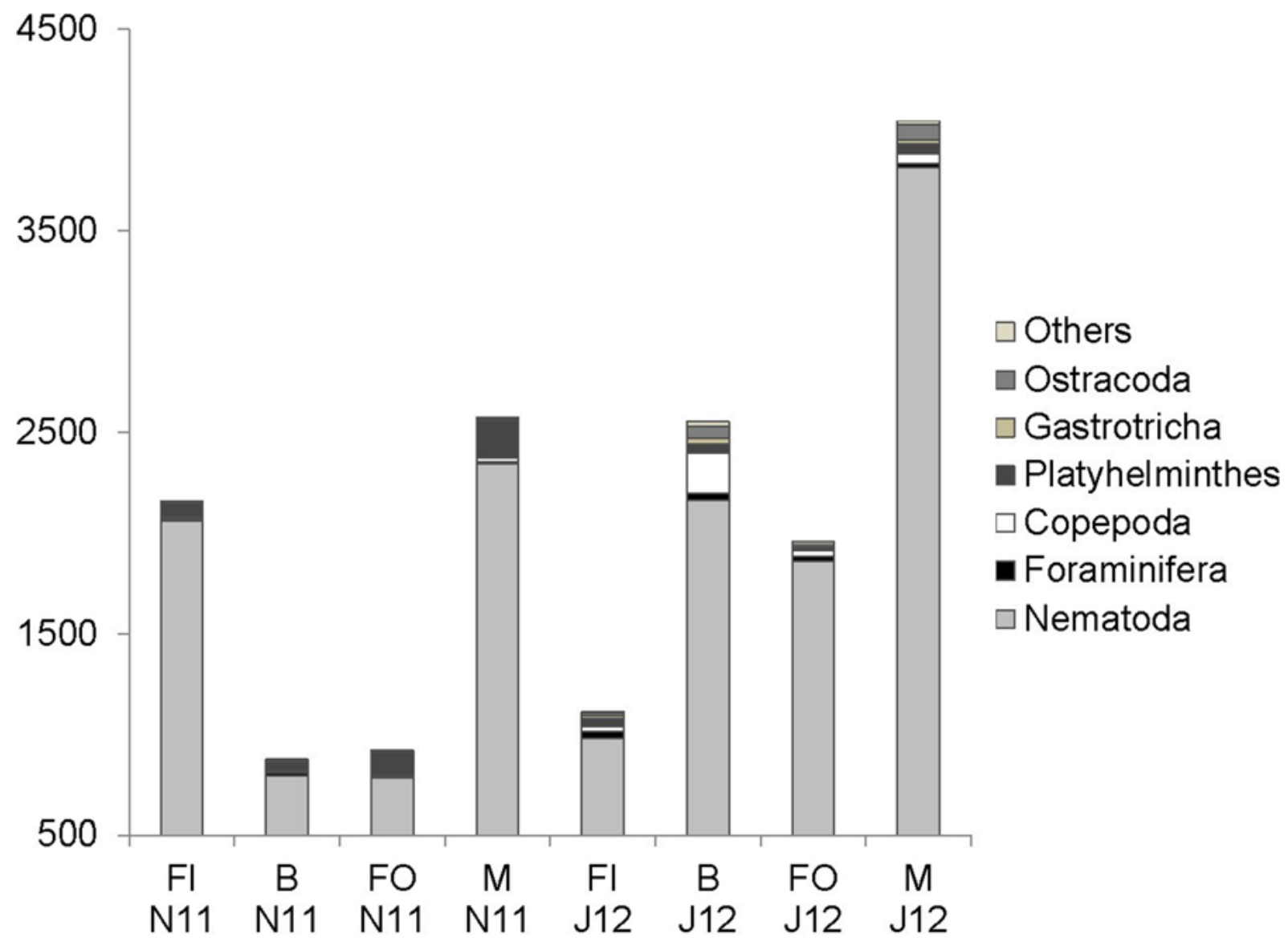

Fig. 3 Meiobenthic abundance and composition in the study area 


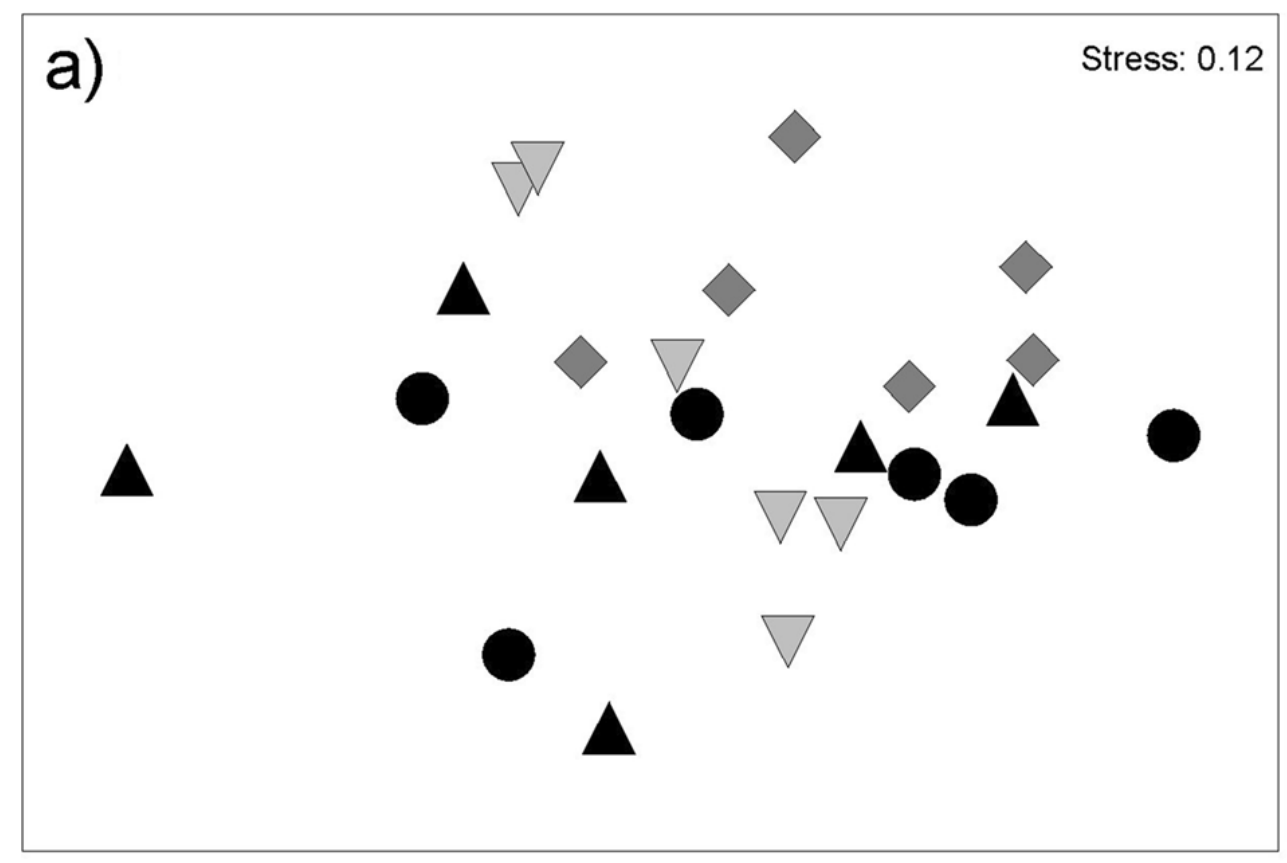

$\triangle$ FO

b)

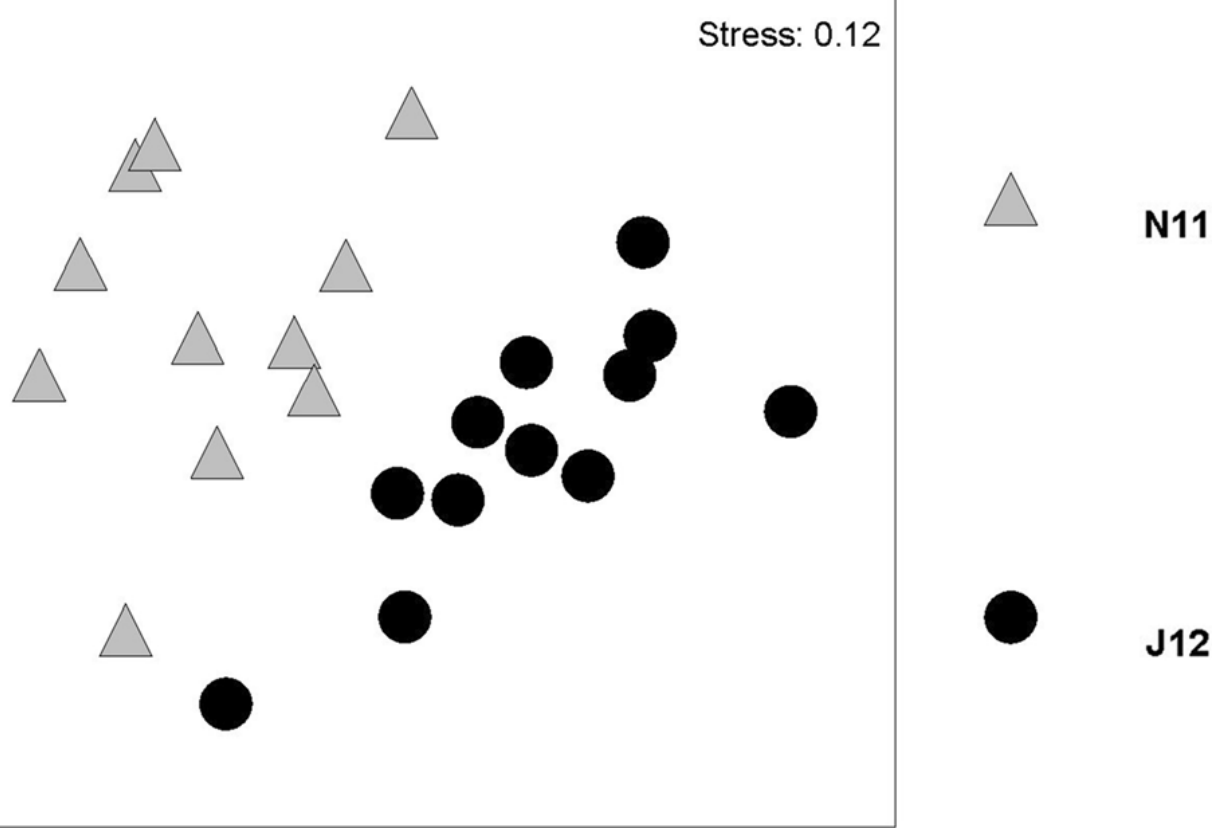

Fig. 4 nMDS plot of meiobenthos assemblages. The symbols represent the variations of the sites (a) or periods (b) 

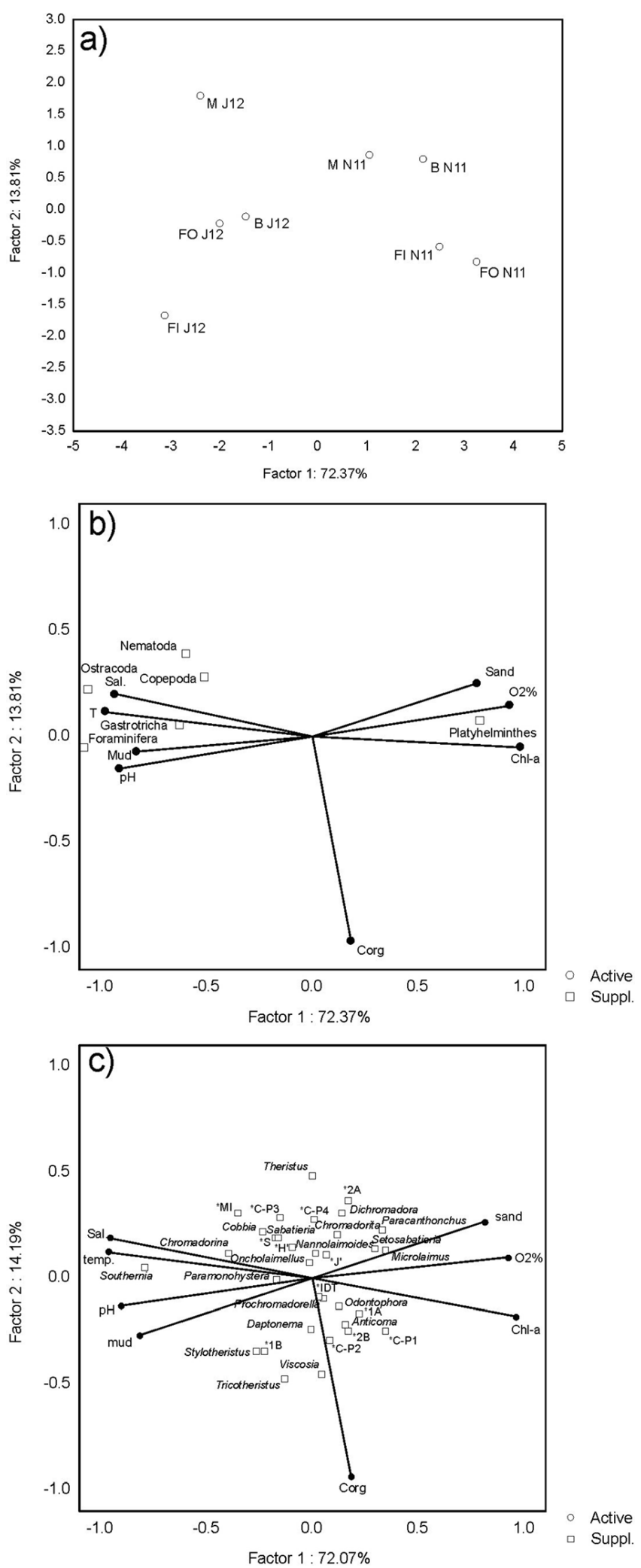

Fig. 5 Scatter diagram (a) plotting factors 1 and 2 of sampling stations. PCA ordination diagram of study area based on the main environmental variables. The relative abundances of the most abundant meiobenthic taxa (b) and nematode genera (c) were projected on the factor plane as supplementary variables without contributing to the results of the analysis 


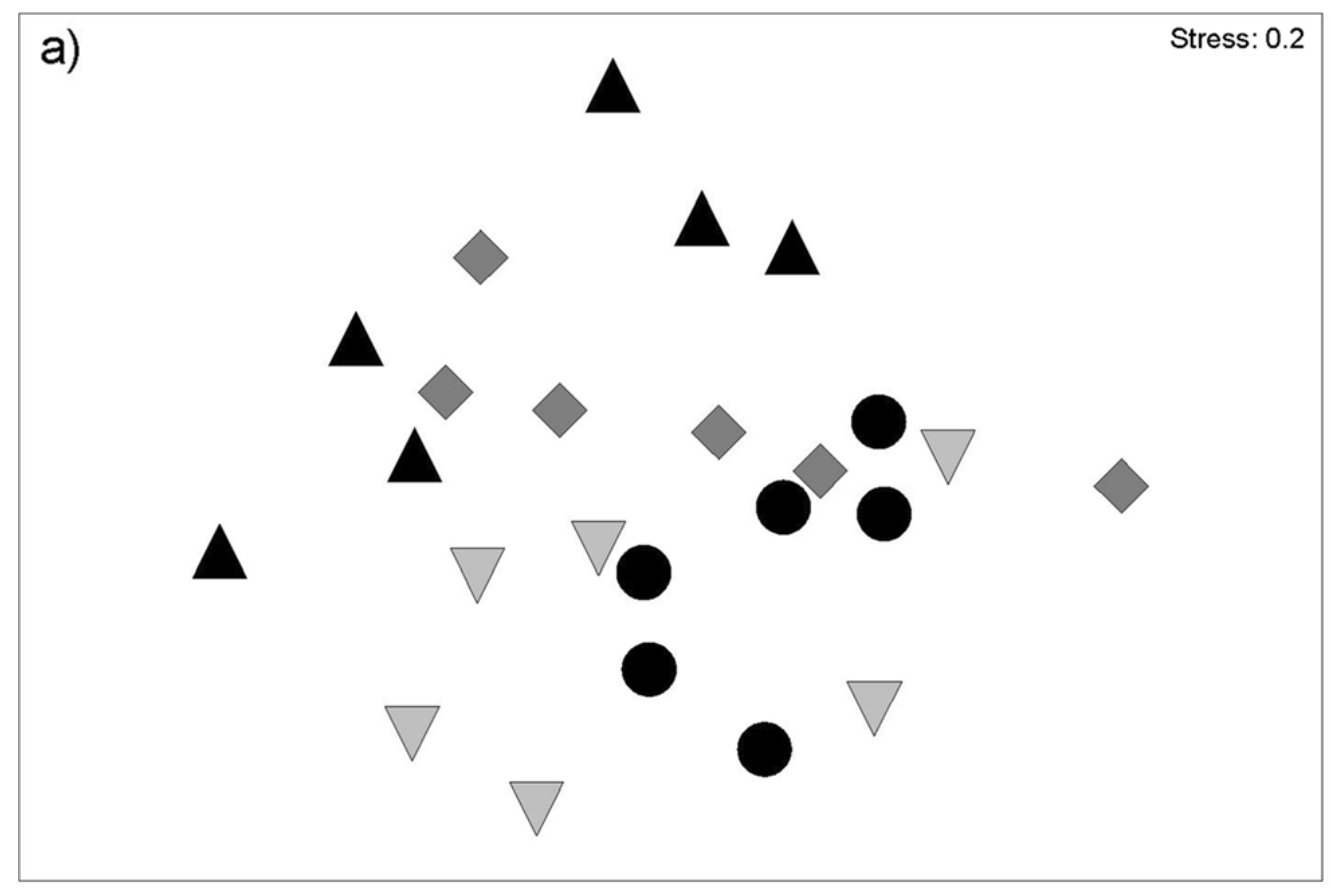

\section{$\triangle$ Fo}

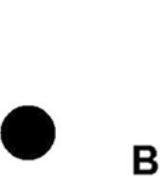

B

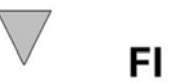

FI

M

b)
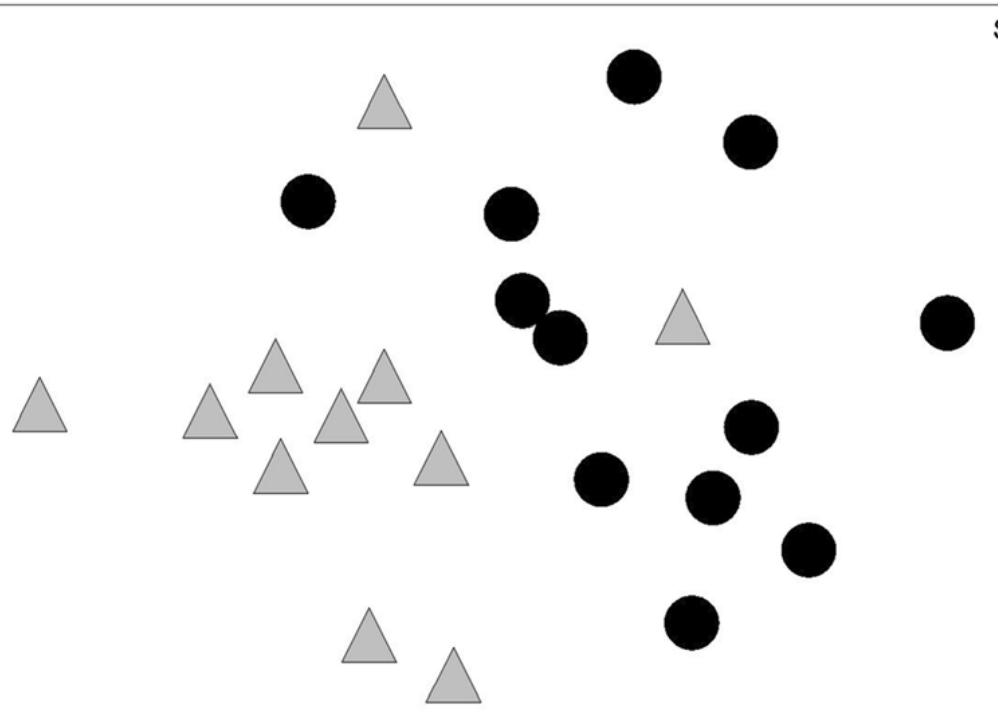

Stress: 0.2

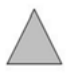

J12

Fig. 6 nMDS plot of nematode assemblages. The symbols represent the variations of the sites (a) or periods (b) 


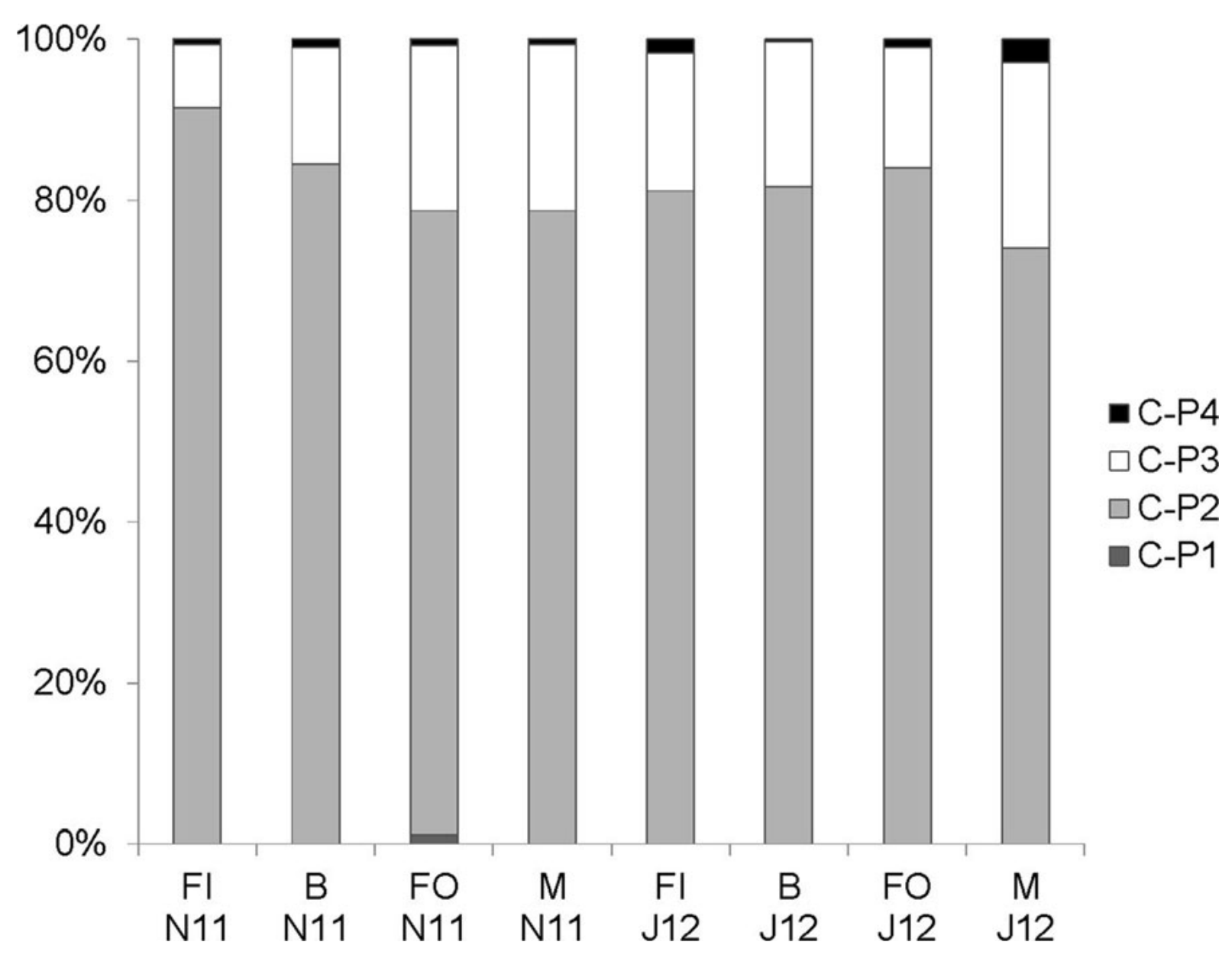

Fig. 7 Percentage of nematode coloniser-persisters classes revealed in the study area 


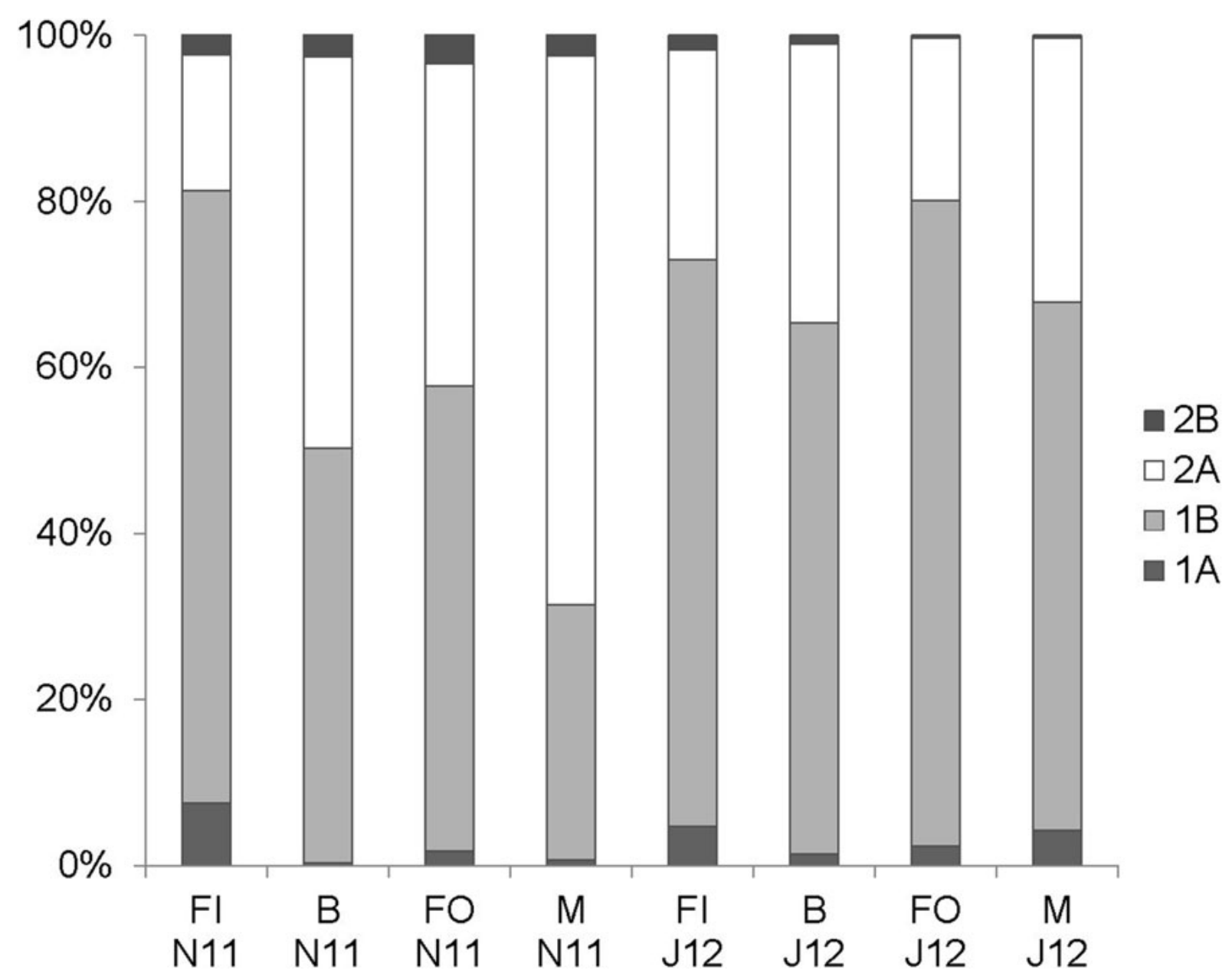

Fig. 8 Percentage of nematode trophic groups revealed in the study area 


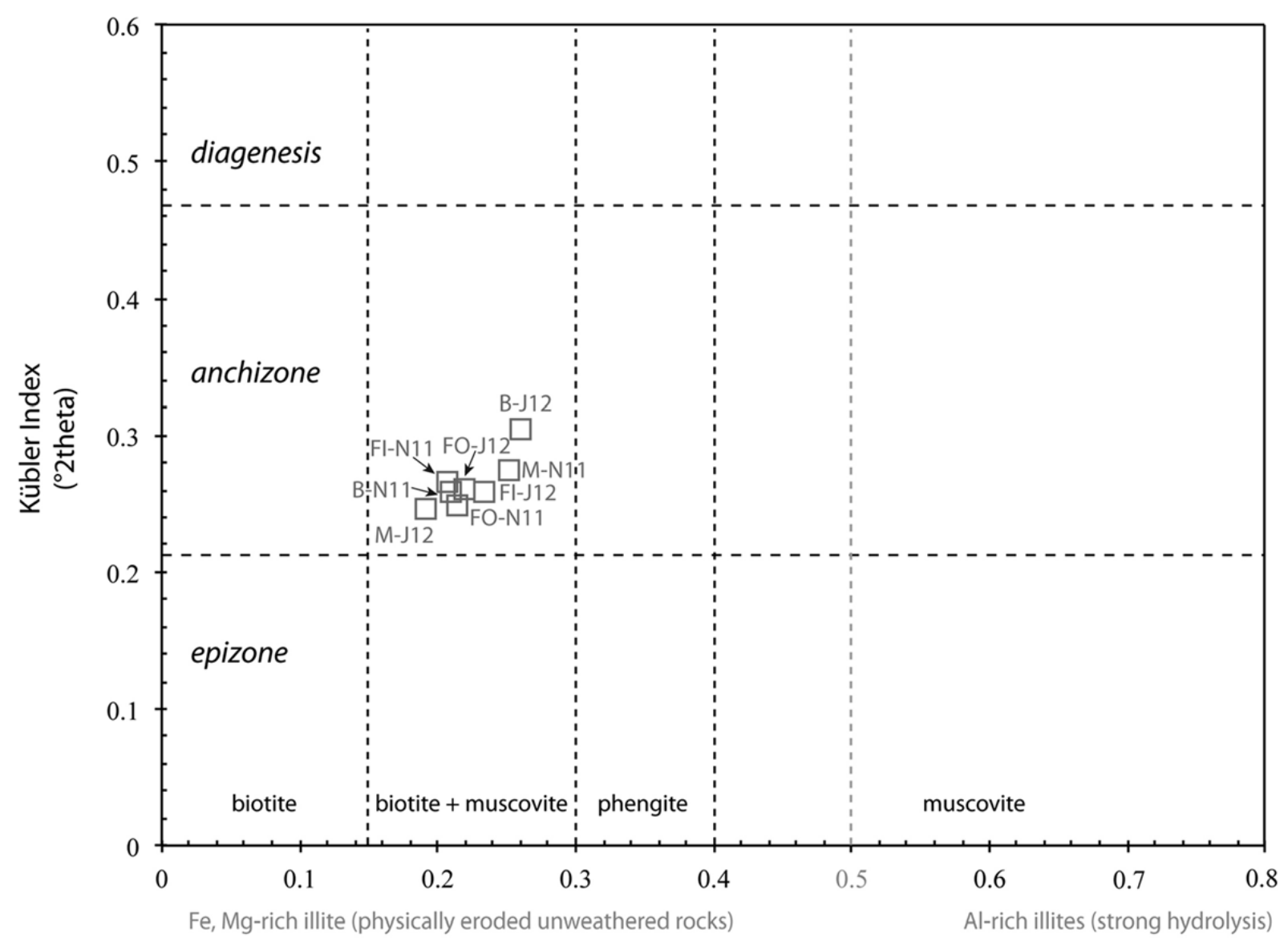

Esquevin Index

$(10 \AA ̊ / 5 \AA ̊)$

Fig. 9 Esquevin index versus Kübler index of the illite particles 
Table 1 Thresholds considered to evaluate the EcoQof the study area according toDanovaro et al. (2004), Marin et al. (2008), Moreno et al. (2011) and Semprucci et al. (2014a, b)

\begin{tabular}{llllll}
\hline & High & Good & Moderate & Poor & Bad \\
\hline TOM $(\%)$ & $<5$ & & $5-10$ & & $>10$ \\
Chl- $a\left(\mu \mathrm{g} \mathrm{F}^{-1}\right.$ ) & $<10$ & & $10-25$ & & $>25$ \\
Meiofaunal richness $(S)$ & $\geq 16$ & $16<S<12$ & $8<S<11$ & $4<S<7$ & $\leq 4$ \\
Nemat ode Shannon index $(H)$ & $>4.5$ & $3.5<H<4.5$ & $2.5<H<3.5$ & $1<H \leq 2.5$ & $0<H^{\prime} \leq 1$ \\
Nemat ode maturity index (MI) & $>2.8$ & $2.8 \leq \mathrm{MI}<2.6$ & $2.6 \leq \mathrm{MI}<2.4$ & $2.4 \leq \mathrm{MI}<2.2$ & $\leq 2.2$ \\
Nemat ode c-p 1 and c-p 2 & $0-20 \%$ & $20-40 \%$ & $40-60 \%$ & $60-80 \%$ & $80-100 \%$ \\
Nemat ode c-p 3 and c-p 4 & $80-100 \%$ & $60-80 \%$ & $60-40 \%$ & $20-40 \%$ & $0-20 \%$ \\
\hline
\end{tabular}

Table 2 Environmental abiotic parameters of each sampling station

\begin{tabular}{|c|c|c|c|c|c|c|c|c|}
\hline & FI N11 & B N11 & FO N11 & M N11 & FI J12 & B J12 & FO J12 & M J12 \\
\hline $\mathrm{T}\left({ }^{\circ} \mathrm{C}\right)$ & 10.87 & 12.05 & 10.39 & 12.08 & 17.33 & 16.98 & 18.33 & 18.67 \\
\hline Salinity (\%o) & 29.06 & 31.37 & 26.37 & 33.31 & 36.53 & 36.62 & 36.47 & 36.33 \\
\hline $\mathrm{O}_{2}(\%)$ & 129.40 & 121.90 & 121.30 & 123.10 & 97.20 & 97.70 & 102.00 & 103.50 \\
\hline $\mathrm{pH}$ & 7.94 & 7.84 & 7.97 & 7.84 & 8.43 & 8.41 & 8.42 & 8.41 \\
\hline ORP & 49.30 & 51.90 & 49.00 & 51.10 & -19.40 & -23.10 & -31.30 & -28.10 \\
\hline Chl- $a(\mu \mathrm{g} /)$ & 20.20 & 13.50 & 25.90 & 11.10 & 0.60 & 0.86 & 0.35 & 0.45 \\
\hline Sand (\%) & 69.83 & 75.39 & 78.61 & 59.92 & 38.11 & 69.07 & 60.82 & 55.00 \\
\hline Silt (\%) & 29.95 & 24.47 & 21.36 & 39.92 & 61.22 & 30.80 & 38.95 & 44.68 \\
\hline Clay (\%) & 0.22 & 0.15 & 0.03 & 0.15 & 0.67 & 0.13 & 0.23 & 0.32 \\
\hline TC (\%) & 5.99 & 5.76 & 6.26 & 6.53 & 6.23 & 5.75 & 6.18 & 6.57 \\
\hline TN (\%) & $<0.1$ & $<0.1$ & 40.1 & $<0.1$ & $<0.1$ & 40.1 & 40.1 & 40.1 \\
\hline TH (\%) & 0.10 & 0.09 & 0.12 & 0.11 & 0.10 & 0.11 & 0.09 & 0.10 \\
\hline TS (\%) & $<0.1$ & $<0.1$ & 40.1 & $<0.1$ & $<0.1$ & 40.1 & 40.1 & $<0.1$ \\
\hline $\mathrm{CaCO}_{3}(\%)$ & 43.97 & 43.63 & 45.95 & 50.44 & 45.44 & 42.56 & 46.17 & 52.17 \\
\hline Corg (\%) & 0.72 & 0.53 & 0.75 & 0.48 & 0.78 & 0.64 & 0.64 & 0.31 \\
\hline Cinorg (\%) & 5.28 & 5.24 & 5.51 & 6.05 & 5.45 & 5.11 & 5.54 & 6.26 \\
\hline Smectite (\%) & 49 & 55 & 58 & 59 & 47 & 54 & 52 & 56 \\
\hline Ilite (\%) & 27 & 24 & 23 & 24 & 27 & 22 & 26 & 26 \\
\hline Chlorite (\%) & 14 & 13 & 11 & 11 & 16 & 13 & 13 & 12 \\
\hline Kaolinite (\%) & 10 & 8 & 7 & 6 & 10 & 10 & 9 & 7 \\
\hline Esquevin indek & 0.21 & 0.21 & 0.22 & 0.25 & 0.23 & 0.26 & 0.22 & 0.19 \\
\hline Kübler index $\left({ }^{\circ} 2 \theta\right)$ & 0.26 & 0.26 & 0.25 & 0.27 & 0.26 & 0.30 & 0.26 & 0.25 \\
\hline Illite/smectite & 0.54 & 0.45 & 0.40 & 0.40 & 0.57 & 0.42 & 0.49 & 0.47 \\
\hline
\end{tabular}


Table 3 Presence (X)/absence (-) of the various taxa found at each station

\begin{tabular}{lllllllll}
\hline & $\mathrm{FIN11}$ & $\mathrm{BN11}$ & $\mathrm{FON11}$ & $\mathrm{M} N 11$ & $\mathrm{FI} \mathrm{J12}$ & $\mathrm{B} \mathrm{J12}$ & $\mathrm{FO} \mathrm{J12}$ & $\mathrm{M}$ J12 \\
\hline Foramini fera & $\mathrm{X}$ & $\mathrm{X}$ & $\mathrm{X}$ & $\mathrm{X}$ & $\mathrm{X}$ & $\mathrm{X}$ & $\mathrm{X}$ & $\mathrm{X}$ \\
Nematoda & $\mathrm{X}$ & $\mathrm{X}$ & $\mathrm{X}$ & $\mathrm{X}$ & $\mathrm{X}$ & $\mathrm{X}$ & $\mathrm{X}$ & $\mathrm{X}$ \\
Copepoda & $\mathrm{X}$ & $\mathrm{X}$ & $\mathrm{X}$ & $\mathrm{X}$ & $\mathrm{X}$ & $\mathrm{X}$ & $\mathrm{X}$ & $\mathrm{X}$ \\
Polychaeta & $\mathrm{X}$ & $\mathrm{X}$ & $\mathrm{X}$ & $\mathrm{X}$ & $\mathrm{X}$ & $\mathrm{X}$ & $\mathrm{X}$ & $\mathrm{X}$ \\
Platyhelminthes & $\mathrm{X}$ & $\mathrm{X}$ & $\mathrm{X}$ & $\mathrm{X}$ & $\mathrm{X}$ & $\mathrm{X}$ & $\mathrm{X}$ & $\mathrm{X}$ \\
Gastrotricha & $\mathrm{X}$ & $\mathrm{X}$ & $\mathrm{X}$ & $\mathrm{X}$ & $\mathrm{X}$ & $\mathrm{X}$ & $\mathrm{X}$ & $\mathrm{X}$ \\
Halacaroidea & - & $\mathrm{X}$ & - & - & - & - & - & $\mathrm{X}$ \\
Bivalvia & - & $\mathrm{X}$ & $\mathrm{X}$ & $\mathrm{X}$ & $\mathrm{X}$ & $\mathrm{X}$ & $\mathrm{X}$ & $\mathrm{X}$ \\
Rotifera & $\mathrm{X}$ & $\mathrm{X}$ & $\mathrm{X}$ & $\mathrm{X}$ & - & - & - & - \\
Oligochaeta & $\mathrm{X}$ & - & - & - & - & $\mathrm{X}$ & $\mathrm{X}$ & $\mathrm{X}$ \\
Ostracoda & - & - & - & $\mathrm{X}$ & $\mathrm{X}$ & $\mathrm{X}$ & $\mathrm{X}$ & $\mathrm{X}$ \\
Amphipoda & - & - & - & $\mathrm{X}$ & - & $\mathrm{X}$ & $\mathrm{X}$ & $\mathrm{X}$ \\
Isopoda & - & - & - & - & - & - & - & $\mathrm{X}$ \\
Cumacea & - & - & - & - & - & $\mathrm{X}$ & - & - \\
Nemertina & - & - & - & - & $\mathrm{X}$ & - & $\mathrm{X}$ & - \\
\hline
\end{tabular}


Table 4 List of nematode genera found at each station

\begin{tabular}{|c|c|c|c|c|c|c|c|c|}
\hline & FI N11 & B N11 & FO N11 & M N11 & FI J12 & B J12 & FO J12 & M J12 \\
\hline Amphimonhystera & 0.00 & 0.00 & 0.00 & 0.00 & 0.00 & 0.00 & 0.00 & 0.33 \\
\hline Anticoma & 6.45 & 0.34 & 0.44 & 0.33 & 2.03 & 0.33 & 0.66 & 1.31 \\
\hline Ascolaimus & 0.00 & 0.00 & 0.00 & 0.00 & 0.34 & 0.00 & 0.00 & 0.33 \\
\hline Axonolaimus & 0.00 & 0.00 & 0.00 & 0.00 & 0.00 & 0.00 & 0.00 & 0.33 \\
\hline Bathyeurystomina & 0.00 & 0.34 & 0.00 & 0.00 & 0.00 & 0.00 & 0.00 & 0.00 \\
\hline Chatonema & 0.00 & 0.00 & 0.00 & 0.33 & 0.00 & 0.00 & 0.00 & 0.33 \\
\hline Chromadora & 0.00 & 1.43 & 0.00 & 0.33 & 0.00 & 0.67 & 0.00 & 0.00 \\
\hline Chromadorella & 0.64 & 0.00 & 0.44 & 0.00 & 0.00 & 0.67 & 0.00 & 0.00 \\
\hline Chromadorina & 0.00 & 0.00 & 0.00 & 0.00 & 0.68 & 2.67 & 0.66 & 0.99 \\
\hline Chromadorita & 0.98 & 4.51 & 2.74 & 6.74 & 1.34 & 4.00 & 0.00 & 1.31 \\
\hline Cobbia & 2.95 & 3.17 & 13.29 & 7.74 & 7.40 & 5.33 & 9.28 & 17.78 \\
\hline Comesa & 0.00 & 0.00 & 0.00 & 0.00 & 0.00 & 0.00 & 0.33 & 0.00 \\
\hline Daptonema & 36.30 & 21.52 & 14.24 & 11.59 & 20.88 & 35.33 & 18.35 & 14.18 \\
\hline Dichromadora & 2.92 & 9.50 & 3.51 & 18.93 & 1.01 & 10.00 & 0.99 & 1.66 \\
\hline Diplolaimelloides & 0.00 & 0.00 & 0.35 & 0.00 & 0.00 & 0.00 & 0.00 & 0.00 \\
\hline Disconema & 0.00 & 0.00 & 0.00 & 0.00 & 0.34 & 0.00 & 0.00 & 0.00 \\
\hline Eleutherolaimus & 0.66 & 0.67 & 0.33 & 0.00 & 0.00 & 0.00 & 0.00 & 0.00 \\
\hline Eumorpholaimus & 0.00 & 0.00 & 0.00 & 0.00 & 0.00 & 0.33 & 0.34 & 0.00 \\
\hline Gammarinema & 0.00 & 0.00 & 0.79 & 0.00 & 0.00 & 0.00 & 0.00 & 0.00 \\
\hline Gnomoxyala & 0.00 & 0.00 & 0.35 & 0.00 & 0.00 & 0.00 & 0.00 & 0.00 \\
\hline Gomphionchus & 0.00 & 0.00 & 0.00 & 0.00 & 0.33 & 0.33 & 0.00 & 0.00 \\
\hline Halalaimus & 0.00 & 0.00 & 0.00 & 0.00 & 0.00 & 0.33 & 0.00 & 0.00 \\
\hline Laimella & 0.00 & 0.00 & 0.00 & 0.00 & 0.00 & 0.00 & 0.00 & 0.33 \\
\hline Linhomoeidae genus 1 & 0.00 & 0.00 & 0.79 & 0.00 & 0.00 & 0.00 & 0.00 & 0.00 \\
\hline Linhomoets | & 0.00 & 0.33 & 0.00 & 0.00 & 0.34 & 0.67 & 0.34 & 1.33 \\
\hline Linhystera & 0.00 & 0.00 & 0.00 & 0.00 & 0.00 & 0.00 & 0.00 & 0.33 \\
\hline Longicyatholaimus & 0.32 & 0.00 & 0.00 & 0.00 & 0.00 & 0.00 & 0.00 & 0.00 \\
\hline Megadesmolaimus & 0.00 & 0.00 & 0.33 & 0.00 & 0.00 & 0.00 & 0.00 & 0.00 \\
\hline Mesacanthion & 0.64 & 0.34 & 0.00 & 0.74 & 0.00 & 0.00 & 0.00 & 0.00 \\
\hline Metacyatholaimus & 0.32 & 0.00 & 0.00 & 0.00 & 0.68 & 0.00 & 0.34 & 0.00 \\
\hline Metalinhomoeus & 0.32 & 0.00 & 0.00 & 0.00 & 0.00 & 0.00 & 1.34 & 0.33 \\
\hline Metasabatieria & 0.32 & 0.00 & 0.00 & 0.00 & 0.34 & 0.00 & 0.00 & 0.00 \\
\hline Microlaimus & 0.97 & 16.43 & 14.39 & 20.44 & 3.37 & 1.00 & 0.67 & 1.67 \\
\hline Molgolaimus & 0.00 & 0.00 & 0.00 & 0.00 & 0.33 & 0.33 & 0.00 & 0.00 \\
\hline Monhysterida & 0.00 & 0.00 & 0.44 & 0.00 & 0.00 & 0.00 & 0.00 & 0.00 \\
\hline Nannolaimoides & 0.65 & 3.89 & 0.00 & 3.67 & 4.01 & 1.67 & 1.98 & 1.64 \\
\hline Nannolaimus & 0.33 & 0.00 & 0.69 & 0.00 & 1.01 & 0.67 & 0.34 & 0.00 \\
\hline Neotonchus & 0.00 & 0.41 & 0.00 & 0.00 & 0.33 & 0.33 & 0.00 & 0.33 \\
\hline Odontophara & 8.48 & 11.29 & 22.68 & 4.74 & 9.73 & 5.67 & 18.90 & 12.53 \\
\hline Oncholaimellus & 0.00 & 0.34 & 2.13 & 0.33 & 0.00 & 0.67 & 1.33 & 1.31 \\
\hline Oncholaimus & 0.00 & 0.00 & 0.00 & 0.00 & 0.00 & 0.00 & 0.00 & 0.33 \\
\hline Paracanthonchus & 1.30 & 3.52 & 0.44 & 2.04 & 0.00 & 0.00 & 0.00 & 0.00 \\
\hline Paracomesoma & 0.00 & 0.00 & 0.00 & 0.00 & 0.00 & 0.00 & 0.00 & 0.32 \\
\hline Paralinhomoeus & 0.00 & 0.67 & 0.44 & 0.33 & 0.00 & 0.00 & 0.00 & 1.00 \\
\hline Paramesacanthion & 0.00 & 0.00 & 0.00 & 0.00 & 0.00 & 0.33 & 0.00 & 0.00 \\
\hline Paramonohystera & 0.00 & 0.00 & 0.33 & 0.67 & 0.00 & 0.00 & 4.35 & 0.00 \\
\hline Pamponema & 0.33 & 0.68 & 0.44 & 0.70 & 0.33 & 0.00 & 0.00 & 0.00 \\
\hline Prochromadorella & 5.18 & 4.00 & 4.07 & 5.48 & 5.09 & 5.00 & 4.61 & 3.63 \\
\hline Sabatieria & 14.04 & 7.67 & 9.81 & 3.00 & 9.08 & 4.00 & 27.20 & 23.12 \\
\hline Scaptrella & 0.00 & 0.00 & 0.00 & 0.00 & 0.00 & 0.33 & 0.00 & 0.00 \\
\hline Setosabatieria & 1.29 & 0.74 & 1.03 & 0.67 & 0.00 & 0.33 & 0.00 & 1.00 \\
\hline Southernia & 0.00 & 0.00 & 0.00 & 0.00 & 1.34 & 0.00 & 1.00 & 2.61 \\
\hline Sphaerolaimus & 0.33 & 0.41 & 0.00 & 0.00 & 0.00 & 0.00 & 0.00 & 0.00 \\
\hline Spilopharella & 0.33 & 0.00 & 0.00 & 0.00 & 0.00 & 0.00 & 0.00 & 0.00 \\
\hline Spininia & 0.00 & 0.00 & 0.00 & 0.00 & 0.00 & 0.33 & 0.00 & 0.00 \\
\hline Stephanolaimus & 0.00 & 0.00 & 0.33 & 0.00 & 0.00 & 0.00 & 0.00 & 0.00 \\
\hline Stylotheristus & 1.29 & 0.41 & 3.35 & 1.00 & 7.08 & 3.67 & 5.35 & 2.66 \\
\hline Terschellingia & 0.00 & 0.00 & 0.33 & 0.33 & 0.00 & 0.00 & 0.33 & 0.00 \\
\hline Theristus & 3.26 & 2.52 & 0.68 & 4.37 & 1.34 & 1.67 & 0.66 & 5.62 \\
\hline Trefusia & 0.33 & 0.00 & 0.00 & 0.00 & 0.00 & 0.00 & 0.00 & 0.00 \\
\hline Tricotheristus & 7.79 & 4.45 & 0.00 & 4.11 & 19.54 & 12.33 & 0.33 & 1.00 \\
\hline Vasostoma & 0.00 & 0.00 & 0.00 & 0.67 & 0.33 & 0.33 & 0.00 & 0.33 \\
\hline Viscosia & 0.96 & 0.41 & 0.79 & 0.70 & 1.35 & 0.67 & 0.33 & 0.00 \\
\hline Xenella & 0.32 & 0.00 & 0.00 & 0.00 & 0.00 & 0.00 & 0.00 & 0.00 \\
\hline
\end{tabular}

